\title{
LEGAL REALISM IN ACTION: INDIRECT COPYRIGHT LIABILITY'S CONTINUING TORT FRAMEWORK AND SONY's DE FACTO DEMISE
}

\author{
Peter S. Menell ${ }^{*}$ \\ David Nimmer
}

The U.S. Supreme Court's indirect copyright liability standard, derived in Sony Corp. of America v. Universal City Studios, Inc. from patent law and reasserted in Metro-Goldwyn-Mayer Studios Inc. v. Grokster, Ltd., is widely seen as creating a safe harbor for distributors of dual-use technologies. Yet, when one looks to cases decided since Sony, subsequent legislative enactments, and post-Sony decisions of technology companies in the marketplace, a different reality emerges. This Article explores and explains the broad gulf between the idealized Sony safe harbor and the practical reality. It shows that the law in many respects reflects the tort principles that more generally undergird copyright liability.

INTRODUCTION

I. TRACING THE EVOLUTION OF INDIRECT COPYRIGHT LIABILITY ............................150

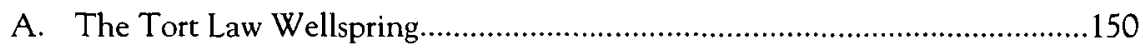

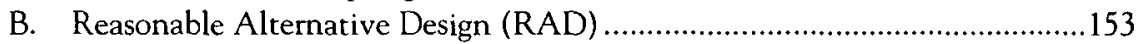

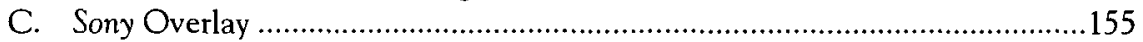

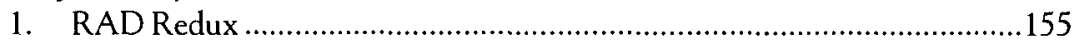

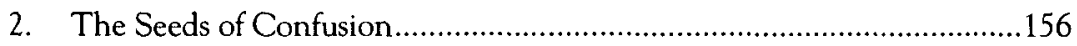

II. ThE LeGiSLATIVE ResPonse to SONY'S "STAPLE ARTIClE

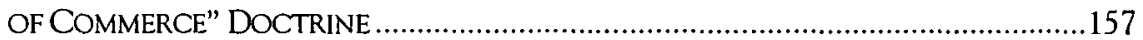

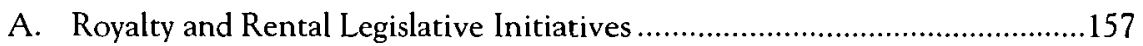

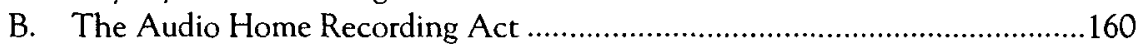

C. The Digital Millennium Copyright Act .......................................................164

1. Anticircumvention Provisions .................................................................164

2. Safe Harbors for Online Service Providers.............................................166

D. Sony's Vector: The Subsequent Congressional Experience ………………......169 
III. The Judicial Response to SONY'S "STAPLe ARTiCle OF COMMERCE" DOCTRINE

A. 1984-2000: Relative Dormancy................................................................173

B. Post-2000: "Staple Article of Commerce" Doctrine Takes

Center Stage.

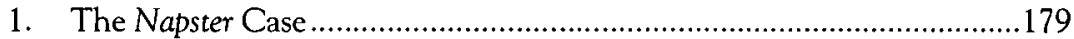

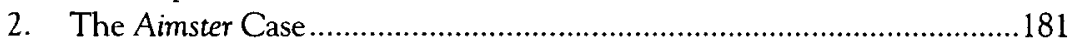

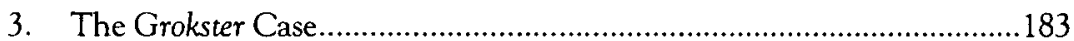

C. Sony's Vector: The Subsequent Judicial Experience .......................................186

IV. THE MARKET'S RESPONSE TO SONY'S "STAPLE ARTICLE OF COMMERCE" DOCTRINE.

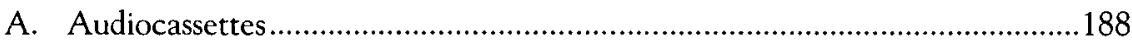

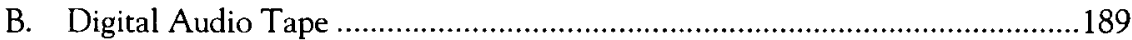

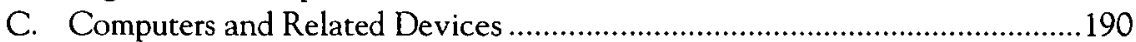

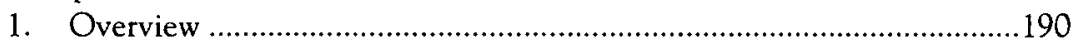

2. Portable Digital Music Devices .............................................................192

3. Digital Encoding Technology ……………………................................193

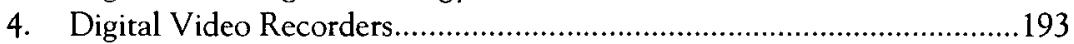

5. Anticircumvention Technology ..........................................................196

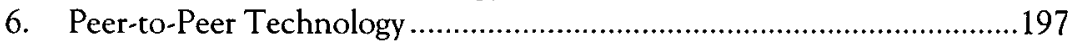

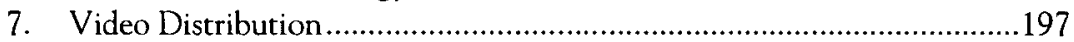

D. Sony's Vector: The Subsequent Marketplace Experience ...............................201

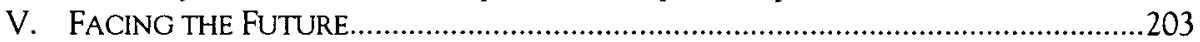

\section{INTRODUCTION}

The U.S. Supreme Court's "staple article of commerce" defense to indirect copyright liability, announced in Sony Corp. of America v. Universal City Studios, Inc., ${ }^{1}$ is widely seen as creating a safe harbor for distributors of dual-use technologies. ${ }^{2}$ Because it immunized from contributory liability not only the makers of the proto-VCR involved in that case (Sony's Betamax), but also manufacturers of any technology that is "merely ... capable of substantial noninfringing use[]," the decision has come to be viewed as the "Magna Carta" of both "product innovation" and the "technology age." As one

1. 464 U.S. 417 (1984).

2. See generally Pamela Samuelson, The Generativity of Sony v. Universal: The Intellectual Property Legacy of Justice Stevens, 74 FORDHAM L. REV. 1831 (2006).

3. Somy, 464 U.S. at 442.

4. Randal C. Picker, Rewinding Sony: The Evolving Product, Phoning Home and the Duty of Ongoing Design, 55 CASE W. RES. L. REV. 749, 753 (2005).

5. See Jessica Litman, The Sony Paradox, 55 CASE W. RES. L. REv. 917, 951-60 (2005); Samuelson, supra note 2, at 1850; Roger Parloff, The Real War Over Piracy; From Betamax to Kazaa a Legal Batte Is Raging Over the "Magna Carta of the Technology Age," FORTUNE MAG., Oct. 27, 2003, at 148. 
commentator notes, "[c]onsumer electronics and computer makers see this ruling as having protected the development and sale of everything from Apple Computer's iPod to an ordinary PC." unquestioning reliance on Sony to address the challenges of the digital age in Metro-Golduyn-Mayer Studios Inc. v. Grokster, Ltd. ' reinforces this perception.

Yet, when one looks to cases decided since Sony, legislative enactments, and the decisions of technology companies in the marketplace, a different reality emerges. With but one exception ${ }^{8}$ (itself effectively overruled by later amendment ${ }^{9}$ ), no reported decision has found the Sony safe harbor to immunize a technology company accused of indirect liability. In fact, the developers and distributors of Napster, Aimster, Grokster, Morpheus, and $\mathrm{KaZaA}$ - peer-to-peer systems that have noninfringing uses-have all been held liable for contributory infringement, Sony notwithstanding. Nor has the U.S. Congress adhered to Sony; instead, its amendments since that case was handed down have expanded copyright liability to reach technologies that are capable of dual use. Technology companies (such as YouTube, BitTorrent, TiVo, and ReplayTV) behave as though they bear responsibility for system designs that create an unreasonable risk of copyright infringement by users of their technology. As explicated in a prior article, ${ }^{10}$ the Supreme Court made several critical mistakes in its Sony decision by importing patent law's "staple article of commerce" safe harbor into copyright law. Instead, the legislative history of the Copyright Act of 1976, ${ }^{11}$ along with copyright decisions reached under the predecessor 1909 Act, ${ }^{12}$ pointed in the direction of tort principles. Such principles would have yielded the same result-shielding Sony from liability based on the unavailability of any reasonably available alternative design for its VCRbut would have provided a better framework for balancing innovation and copyright protection.

6. John Borland, File Swapping ws. Hollywood, CNET NEWS.COM, Jan. 25, 2005, http://news.zdnet.com/2100-9588_22-5548781.html. The "ordinary PC" actually predates Sony by several years. See Andrew Pollack, Big I.B.M.'s Little Computer, N.Y. TIMES, Aug. 13, 1981, at D1.

7. 545 U.S. 913 (2005).

8. See Vault Corp. v. Quaid Software Ltd., 847 F.2d 255 (5th Cir. 1988). The defendant had reverse engineered the plaintiff's copy-protection software and was selling a software product that circumvented this technology.

9. See Digital Millennium Copyright Act, Pub. L. No. 105-304, 112 Stat. 2860 (1998) (codified at 17 U.S.C. $\$ \$ 1201(\mathrm{a})(2), 1201(\mathrm{~b})(1)(2000)$ ) (imposing liability on companies trafficking in decryption keys that circumvent technological protection measures).

10. See Peter S. Menell \& David Nimmer, Unwinding Sony, 95 CAL. L. REV. 941 (2007).

11. Pub. L. No. 94-553, 90 Stat. 2541 (codified as amended at 17 U.S.C. $\$ \S 101-1101$ (2000)).

12. Ch. 320,35 Stat. 1075 (1909). 
This Article explores and explains the broad gulf between the idealized (and idolized) Sony safe harbor and the practical reality. A close look at the legislative, judicial, and market reactions to the case reveals that the shift from tort law to patent standards has been essentially cosmetic.

Turning first to the legislative response to the Sony decision, Congress did not rush in either to save the motion picture industry or to correct the Supreme Court's wrong turn. ${ }^{13}$ Congress is an overextended, agenda-driven institution. Although it engages at times in deliberative efforts to update and systematically revise laws, as was the case with the Copyright Act of 1976, it more often deals with the salient matters of the day rather than fixing problems that may never manifest. ${ }^{14}$ Therefore, it is not surprising that Congress did not directly take up the question whether the Sony staple article of commerce rule comported with the 1976 Act and revise it accordingly. The outcome of the Sony case comported with a proper interpretation of the Copyright Act of 1976 and the views of a significant majority of Americans, as well as their legislators. Following the decision, movie studios lobbied Congress for imposition of a levy on VCRs and tapes and a video rental right, to no avail. As the digital age dawned in the late 1980s and 1990s, however, Congress enacted two pieces of legislation that contradict and at least partially overrule the broad safe harbor that Sony read into the Copyright Act of 1976. Anachronistically viewed, these enactments cast doubt on the Sony majority's bold assertion that Congress intended blanket immunity for those who manufacture and distribute products that are merely capable of substantial noninfringing use. Yet, they do not address the more general question whether Congress (either as of 1976 or as of those later amendments) supports the staple article of commerce safe harbor under copyright law. So, the legislative record fails to definitively resolve Sony's status.

Turning next to the judicial response, from 1984 until 2000, the Supreme Court's staple article of commerce holding received little judicial attention. ${ }^{15}$ The situation changed dramatically in 2000, in the aftermath of Napster and the peer-to-peer revolution. The discussion below examines the trio of digital age peer-to-peer technology cases-AEM Records, Inc. v.

13. See infra Part II.

14. Nonetheless, fear of what seemed around the corner has at times induced the U.S. Congress to adopt amendments to the Copyright Act of 1976 regarding problems that never have manifested, with unfortunate results. See David Nimmer, Codifying Copyright Comprehensibly, 51 UCLA L. REV. 1233, 1327-44 (2004) (detailing such amendments as those concerning digital tape, semiconductor chips, and vessel hulls).

15. See infra Part III.A. 
Napster, Inc., ${ }^{16}$ In re Aimster Copyright Litigation, ${ }^{17}$ and Metro-GoldwynMayer Studios Inc. v. Grokster, Ltd. ${ }^{18}$ (that last in its pre-Supreme Court instantiation $)^{19}$ - to glean the vitality of copyright law's staple article of commerce doctrine. ${ }^{20}$ Although none directly countermands the staple article of commerce rule, each imposes liability on parasitic business models notwithstanding that all those models plausibly facilitated both actual and potential noninfringing use. In varying degrees, these decisions avoid the broad implications of Sony in order to restore some of the balance and dynamism that Congress intended in the liability provisions of the 1976 Act. Nonetheless, the manner in which the courts have achieved this equipoise was neither direct nor candid, resulting in an undesirable muddling of the law.

The last inquiry examines the marketplace effects of Sony. ${ }^{21}$ It surveys the business and strategy decisions in consumer electronics and the computer marketplace over the two decades following Sony. Although there is reason to believe that the case exerted some restraining influence on content industries, it would be an exaggeration to conclude that technology companies have enjoyed broad immunity from litigation or that other approaches to indirect liability-whether the Sony dissent's "primary use" test or the tort-based "reasonable alternative design" (RAD) framework" would have resulted in substantially different market outcomes. In fact, the pattern since the Sony decision shows greater resemblance to a RAD-based regime than to a broad staple article of commerce safe harbor.

In light of these considerations, how should Sony's staple article of commerce doctrine be understood? At one extreme, the Supreme Court's decision could be read as splicing $\$ 271$ (c) of the Patent Act $^{23}$ directly into the Copyright Act of 1976 for all future cases. At the other, the decision could be understood solely as resolving Sony Corporation's indirect liability as of 1984, leaving future courts free to interpret the Copyright Act as needed to resolve the issues posed by later technologies. If the rule were limited to the specific facts of the Sony case, the concerns raised herein would be of only historical significance. But notwithstanding the Sony

16. 114 F. Supp. 2d 896 (N.D. Cal. 2000), aff'd in part, rev'd in part, 239 F.3d 1004 (2001).

17. 334 F.3d 643 (7th Cir. 2003), cert. denied sub nom., Deep v. Recording Indus. Ass'n of Am. (RIAA), 540 U.S. 1107 (2004).

18. 380 F.3d 1154 (9th Cir. 2004).

19. The final installment of this trilogy focuses on the U.S. Supreme Court version of Metro-Goldwyn-Mayer Studios Inc. v. Grokster, Ltd. See infra note 221.

20. See infra Part III.B.

21. See infra Part IV.

22. See infra Part I.B.

23. 35 U.S.C. $\$ 271$ (c) (2000). 
majority's professed caution in drawing upon a provision of another statute in interpreting silence in a later enactment, the staple article of commerce rule that the Court adopted holds broad ramifications for the digital age. Digital technology industries have contended that this was all for the good, applauding the freedom to invent that the staple article of commerce principle promotes. ${ }^{24}$ Content industries have worried that such immunity for foreseeable, potentially rampant harms threatens to disrupt important markets and to hamper artists' and producers' ability to distribute their works through the most effective channels.

Subsequent history supports the wisdom of the Sony outcome at the same time that it vindicates both the hopes of the technology industries and the fears of the content industries. Rather than destroy the film industry - as Jack Valenti infamously predicted ${ }^{25}$ - the VCR proved a great boon to motion picture studios, consumer electronics makers, and consumers alike. ${ }^{26}$ In little more than a decade after the Court ruled, the sale and rental of videotapes eclipsed box office revenues. ${ }^{27}$ Although a contrary result in Sony might possibly have led to the development of a market for playback-only video devices or a licensing framework, it seems unlikely that consumers would have adopted that hypothetical technology nearly as fast as they actually purchased VCRs, fueling the rapid expansion of the video sale and rental marketplace in the mid- to late 1980s. Yet, even though the studios' dire predictions of harm from the VCR have not come to pass, new forms of digital technology-such as largely anonymous peer-to-peer distribution systems-have disrupted content markets and complicated the rollout of vast libraries of content. ${ }^{28}$ The Sony safe harbor has spawned an environment in which some technologists design software and products based not on what is socially optimal-in terms of balancing functionality

24. See Borland, supra note 6.

25. See Home Recording of Copyrighted Works: Hearings Before the Subcomm. on Courts, Civil Liberties, and the Admin. of Justice of the H. Comm. on the Judiciary, 97th Cong. 8 (1982) (statement of Jack Valenti, President, Motion Picture Association of America, Inc.) (suggesting that "the VCR is to the American film producer and the American public as the Boston strangler is to the woman home alone").

26. See infra Part II.A.

27. See Harold L. VOGEl, ENTERTAINMENT INDUSTRy ECONOMICS: A GUIDE FOR FINANCIAL ANALYSIS 62 (5th ed. 2001); see also Lauren Lipton, VCR (Very Cool Revolt): Home-Taping Habits Are Lagging Behind Original Predictions, L.A. TIMES, Aug. 4, 1991, at TV Times 2 (reporting that use of VCRs to record television programming had dropped significantly and just 11 percent of households with VCRs were responsible for more than half of all the taping that occurred).

28. See infra Part III.B. 
against adverse impacts - but rather on how to avoid liability for clearly foreseeable and manageable harms. ${ }^{29}$

This Article takes no position regarding whether product Pollyannas or content Cassandras are closer to the truth. For reasons previously explained, ${ }^{30}$ we endorse the outcome of the Sony case at the same time that we question the jurisprudential basis for the Supreme Court's importation into copyright law of a broad safe harbor from patent law. ${ }^{31}$ Although Congress's intention on the issue of indirect copyright liability as of the 1976 Act was inchoate with regard to the challenges of the digital age, the tort principles that have guided copyright law since its inception should continue to guide copyright's further evolution. Although concededly possible, it would be purely adventitious for the Supreme Court's unsystematic analysis in the Sony case in 1984 to have determined the optimal public policy for dramatic new technologies developing in 2007 and future years. Therefore, until Congress itself is prepared to surmount the challenges of the digital age by legislating direct solutions geared to its challenges, we believe the traditional tort framework offers a balanced and dynamic mechanism for addressing the many challenges of adapting copyright law to new technology.

29. See infra Part IV.C. Using Sony as a guide, counsel to one of the Grokster defendants offered the following checklist for designing peer-to-peer software enterprises to avoid liability:

Can you plausibly deny what your users are up to? ...

Have you built a level of 'plausible deniability' into your product architecture? If you promote, endorse, or facilitate the use of your product for infringing activity, you're asking for trouble. ... Software that sends back user reports may lead to more knowledge than you want. Customer support channels can also create bad "knowledge" evidence. Instead, talk up your great legitimate capabilities, sell it (or give it away), and then leave the users alone.

Disaggregate functions .... In order to be successful, peer-to-peer networks will require products to address numerous functional needs-search, namespace management, security, dynamic file redistribution, to take a few examples. There's no reason why one entity should try to do all of these things. ...

This approach may also have legal advantages. If Sony had not only manufactured VCRs, but also sold all the blank video tape, distributed all the TV Guides, and sponsored clubs and swap meets for VCR users, the Betamax case might have turned out differently.... A disaggregated model, moreover, may limit what a court can order you to do to stop infringing activity by your users.

Fred von Lohmann, Elec. Frontier Found., IAAL [I am a Lawyer]: What Peer-to-Peer Developers Need to Know About Copyright Law, § V.7 (Dec. 2003), quoted in Intentional Inducement of Copyright Infringements Act of 2004: Hearing Before the S. Comm. on the Judiciary, 108th Cong. (2004) (statement of Marybeth Peters, The Register of Copyrights), available at http://www.copyright.gov/docs/regstat072204.html.

30. See Menell \& Nimmer, supra note 10.

31. See infra Part $\mathbf{I}$. 


\section{TRACING THE EVOLUTION OF INDIRECT COPYRIGHT LIABILITY}

Before considering reactions to Sony, it is necessary first to recall the backdrop against which the Supreme Court rendered its decision. This Part highlights the Supreme Court's error in framing the indirect liability standard. It concludes by sketching the framework that the Court would have enunciated had it properly considered the legislative and jurisprudential moorings of indirect copyright liability.

\section{A. The Tort Law Wellspring}

The first installment in this series meticulously reviewed the forces leading up to the Supreme Courr's Sony decision. ${ }^{32}$ Sony's importation of patent law's staple article of commerce doctrine rested on the critical inference that a "historic kinship between patent and copyright" justifies looking to patent law to address an analogous issue under copyright law. ${ }^{33}$ Sony's lead counsel actually planted the seed in the district court proceedings of importing patent law's staple article of commerce doctrine-that products capable of substantial noninfringing use escape liability-into copyright law. ${ }^{34}$ Lacking experience with copyright law, facing a complex, recently enacted statute and even more daunting case law, and sensing the unprecedented nature of the plaintiffs' assertion of liability, Judge Ferguson found that suggestion enticing. ${ }^{35}$

Eventually, the Supreme Court followed suit. The grand compromise that produced the Supreme Court majority did not turn on analytic review of the statute, its legislative history, or copyright jurisprudence. Rather, it reflected a loose and expedient policy determination that copyright law should follow the patent law model. The task was left to Justice Stevens, as craftsman of the majority opinion, to come up with a rationale for importing patent laweven though he himself had previously favored an alternative manner of resolving the case. ${ }^{36}$ But his inference of a "historic kinship" between the two regimes fails to stand up to historical and jurisprudential scrutiny.

32. See Menell \& Nimmer, supra note 10.

33. Sony Corp. of Am. v. Universal City Studios, Inc., 464 U.S. 417, 439 (1984).

34. See Menell \& Nimmer, supra note 10 , at 947 .

35. Id. at $951-52$.

36. Justice Stevens previously stated that the case should be resolved by finding an implied immunity for home recording buried within the legislative history of the Sound Recording Act of 1971 and the Copyright Act of 1976. See Letter from Justice John Paul Stevens to Justice Harry A. Blackmun (Jan. 24, 1983) (copy on file with the UCLA Law Review). 
Sony's majority bolstered its critical "historic kinship" rationale by citing three cases. ${ }^{37}$ The first two dealt simply with the "asset" nature of copyrights-one was an antitrust suit under the Sherman Act charging studios with monopolizing the production of motion pictures; ${ }^{38}$ the other, a tax case, tested whether copyrights, being instrumentalities of the federal government, were subject to the power of state authorities to collect taxes on gross receipts of royalties. ${ }^{39}$ Neither addressed the contours of copyright protection nor supports determining the scope of copyright liability by reference to patent law. The third case is weaker still, merely standing for the proposition that nonstatutory (common law) doctrines of patent law track nonstatutory considerations applicable to copyright law. ${ }^{40}$ Far from bolstering the proposition that a feature of statutory law can be read from patent onto copyright law, that case instead shows fidelity to "a strict conformity to the law" by which Congress enacted each area of law." That holding therefore undercuts Sony's later overlay of the patent statute as enacted on top of the different enactment of a copyright statute.

As opposed to a "historic kinship," investigation reveals that both copyright and patent law flow from the common wellspring of tort law. As far back as 1869 , courts recognized that "[r]ights secured by copyright are property within the meaning of the law of copyright, and whoever invades that property beyond the privilege conceded to subsequent authors commits a tort." ${ }^{, 42}$ Thus, it was nothing new when the Second Circuit observed in 1923 that "infringement of a copyright is a tort." Courts looked to the law of torts to determine the boundaries of copyright liability-in the process invoking a panoply of familiar tort doctrines. From the late nineteenth century through the passage of the Copyright Act of 1976, courts developed copyright liability based on general tort principles, such that indirect copyright doctrines emerged in tort law's image:

Respondeat Superior. In M. Witmark $\mathscr{E}$ Sons v. Calloway, ${ }^{44}$ a music publisher brought suit against a theater owner who employed a person to select copyrighted music to be publicly performed on a player piano.

37. 464 U.S. at 439 n.19 (citing United States v. Paramount Pictures, Inc., 334 U.S. 131, 158 (1948); Fox Film Corp. v. Doyal, 286 U.S. 123, 131 (1932); Wheaton v. Peters, 33 U.S. 591, 657-658 (1834)).

38. Paramount Pictures, 334 U.S. at 140.

39. Fox Film, 286 U.S. at 126.

40. Wheaton, 33 U.S. at 657-58.

41. Id. at $663-664$.

42. Lawrence v. Dana, 15 F. Cas. 26, 61 (C.C. Mass. 1869) (No. 8,136).

43. Ted Browne Music Co. v. Fowler, 290 F. 751, 754 (2d Cir. 1923).

44. 22 F.2d 412 (E.D. Tenn. 1927). 
The court held the owner liable, even though the employee's acts may have been done against orders. ${ }^{45}$

Vicarious Liability. The courts would ensnare dance hall operators within the net of indirect liability due to their ability to control the use of their facilities (even by independent contractors) and derive profit from the illegal activity. ${ }^{46}$ In Shapiro, Bernstein \& Co. v. H.L. Green Co., ${ }^{47}$ the Second Circuit held liable a chain of department stores that leased a record concession to the direct infringer, who manufactured and sold bootleg recordings of copyrighted musical compositions. The lease based rental fees on the lessee's gross revenues. Notwithstanding the direct infringer's independent contractor-lessee status, the court expanded indirect copyright liability to reach the profit participant. ${ }^{48}$

Contributory Liability (including inducement). The Supreme Court recognized contributory copyright infringement in $1908,{ }^{49}$ embroidering on that ruling three years later in Kalem Co. v. Harper Bros., ${ }^{50}$ in which the defendant had prepared a motion picture based upon the plaintiff's copyrighted novel, Ben Hur. Because then-applicable copyright law barred only the dramatization of the copyrighted work, ${ }^{\text {s1 }}$ direct copyright liability could only be asserted against those who publicly performed the work. Therefore, the copyright owner proceeded against the makers of the unauthorized film under a contributory infringement theory and prevailed on that basis. ${ }^{52}$ The Second Circuit further delineated the standards for contributory copyright liability in Gershwin Publishing Corp. v. Columbia Artists Management, ${ }^{53}$ imposing liability on a talent promotion agency that knowingly booked performances in venues lacking public performance licenses. The court succinctly captured the elements of contributory copyright liability: "One who, with knowledge of the infringing activity,

45. Id. at 414 .

46. See Dreamland Ball Room, Inc., v. Shapiro, Bernstein \& Co., 36 F.2d 354 (7th Cir. 1929). The Supreme Court gave its imprimatur to such indirect liability in Buck v. Jewell-La Salle Realty Co., 283 U.S. 191, 198-99 (1931); later rulings extended this doctrine. See KECA Music, Inc. v. Dingus McGee's Co., 432 F. Supp. 72 (W.D. Mo. 1977); Buck v. Crescent Gardens Operating Co., 28 F. Supp. 576, 578 (D. Mass. 1939); Buck v. Newsreel, Inc., 25 F. Supp. 787 (D. Mass. 1938).

47. 316 F.2d 304 (2d Cir. 1963).

48. Id. at 307 .

49. See Scribner v. Straus, 210 U. S. 352 (1908).

50. 222 U.S. 55, 62-63 (1911).

51. See Act of March 3, 1891, ch. 565, 26 Stat. 1106-07 (1891).

52. Scribner, 222 U.S. at 62-63.

53. 443 F.2d 1159 (2d Cir. 1971). 
induces, causes or materially contributes to the infringing conduct of another, may be held liable as a 'contributory' infringer."

Thus, the law of indirect copyright liability was firmly established by the 1970s. Courts had drawn on the principles of tort liability and the policies of the copyright system to weave a sophisticated web of indirect liability doctrines addressing the distinctive challenges of enforcing copyright law.

The 1976 Act expressly extended the reach of copyright protection by stating that liability applied not only to those who "do" infringing acts but also to those who "authorize" such acts. ${ }^{55}$ The legislative history clarifies that Congress intended to perpetuate in its comprehensive reform previous indirect copyright doctrines as well as incremental application of general tort principles. The Senate and House Reports refer specifically to the law of torts: "[W]here the work was infringed by two or more joint tort feasors, the bill would make them jointly and severally liable." ${ }^{56}$ They also directly reference indirect liability standards. In explaining the general scope of copyright, the House Report recognizes both contributory liability $^{57}$ and vicarious liability. ${ }^{58}$ Those citations cement Congress's intent to preserve the tort principles that courts had developed under prior copyright regimes.

\section{B. Reasonable Alternative Design (RAD)}

What principles of tort law apply to manufacturers and distributors of technologies that can cause harm? Someone who profits from activities that cause harm and is in a good position to supervise those activities can be held responsible in various contexts. One manifestation of this principle,

54. Id. at 1162 .

55. See 17 U.S.C. \& 106 (2000 \& Supp. II 2002)

56. S. REP. NO. 94-473, at 144 (1975); H.R. REP. NO. 94-1476, at 162 (1976) (same, but spelling "tortfeasors" as one word); see H. COMM. ON THE JUDICIARY, SUPPLEMENTARY REPORT OF THE REGISTER OF COPYRIGHTS ON THE GENERAL REVISION OF THE U.S. COPYRIGHT LAW: 1965 ReVISION Bill 136 (Comm. Print 1965).

57. See H.R. REP. NO. 94-1476, at 61 ("The exclusive rights accorded to a copyright owner under section 106 are 'to do and to authorize' any of the activities specified in the five numbered clauses. Use of the phrase 'to authorize' is intended to avoid any questions as to the liability of contributory infringers." (emphasis added)).

58. See id. at 159-60 ("To be held a related or vicarious infringer in the case of performing rights, a defendant must either actively operate or supervise the operation of the place wherein the performances occur, or control the content of the infringing program, and expect commercial gain from the operation and either direct or indirect benefit from the infringing performance. The committee has decided that no justification exists for changing existing law, and causing a significant erosion of the public performance right."). 
just noted, is respondeat superior. Another emerges from products liabilitythe body of law intended to promote safe product design while balancing incentives to innovate, manufacture, and distribute products that have beneficial uses. Product manufacturers can reduce harm through better design, quality control in manufacturing and testing, and the instructions that they provide for use of products. Though its roots trace back centuries, product liability law reached full fruition in this country by the early 1960s, when courts

recogniz[ed] that a commercial seller of any product having a manufacturing defect should be liable in tort for harm caused by the defect regardless of the plaintiff's ability to maintain a traditional negligence or warranty action. Liability attached even if the manufacturer's quality control in producing the defective product was reasonable. A plaintiff was not required to be in direct privity with the defendant seller to bring an action. ${ }^{59}$

Courts also extended liability upstream to the design stage. Under the most recent codification of tort principles, a product is defective in design when its foreseeable risks of harm could have been reduced or avoided though the adoption of a RAD by the seller, other distributor, or a predecessor in the commercial chain of distribution, and the omission of the alternative design renders the product not reasonably safe..$^{60}$ Imposing upstream liability for such effects creates valuable ongoing incentives to prevent and reduce harm. The risk of downstream liability encourages manufacturers to take appropriate precautions. It also reduces the consumption of unreasonably risky products by increasing their cost, making them less competitive in the marketplace. ${ }^{61}$

To illustrate, a defective bolt in an automobile braking system can cause harm long after it is made and many miles down the road. By imposing liability on the manufacturer, the law forces automobile equipment manufacturers, as well as those who inspect the product along the stream of commerce, to internalize the harm at the most efficacious points in time. Even if the bolt were properly manufactured, it might have been better for the manufacturer to have used an alternative design. Such judgments, however, are inherently speculative. Products are not defective merely because they are dangerous. Automobiles that could travel no more than twenty miles per hour would undoubtedly reduce the number and severity

60. Id. $\$ 2$.

61. See Guido Calabresi, The Cost of ACCidents 68-75 (1970). 
of accidents, but not without substantial social cost. Design defectiveness entails a multifaceted balancing of risk and utility. ${ }^{62}$ This process entails examination of the magnitude and probability of the foreseeable risks of harm, the instructions and warnings accompanying the product, the nature and strength of consumer expectations regarding the product, production costs of alternative designs, and attributes of the alternative design (product longevity, maintenance, repair, and aesthetics). ${ }^{63}$

It would be unduly burdensome to require manufacturers to prove that their products embody the most appropriate design. Rather, courts require plaintiffs to establish the feasibility, as of the time of manufacture, of a RAD that would have reduced the foreseeable risks of harm. In essence, plaintiffs must show that a RAD was reasonably foreseeable to product manufacturers. In this way, the legal standard has a dynamic quality, the threshold for precaution rising with technological advance. ${ }^{64}$

\section{Sony Overlay}

1. RAD Redux

Plaintiffs in Sony sought to pursue a design defect theory through testimony from an engineer that Sony could have designed its VCR to record only programs broadcast with authorization to make copies. ${ }^{65}$ Putting aside technical details—as well as the need to coordinate among many industry players and problems of circumvention-such evidence would have been relevant to prove the availability of an alternate design. Questions would remain: Was that alternative design then "available"? Could plaintiffs convincingly demonstrate that reduction in the risk of harm outweighed the loss in utility?

Our previous analysis showed that technically feasible design alternatives available to Sony at the time of the litigation (such as banning remote control devices and blocking the fast-forward feature) would not have been justified based on product liability law's risk-utility tradeoff. Such design changes would have unduly impaired legitimate uses of VCRs (such as time-shifting) without significantly reducing potential illegal uses

62. See David G. Owen, Toward a Proper Test for Design Defectiveness: "Micro-Balancing" Costs and Benefits, 75 TEX. L. REV. 1661 (1997).

63. See Restatement (THIRD) OF TORTS: PRODUCTS Liability $\$ 2 \mathrm{cmt}$. $\mathrm{f}(1998)$.

64. See id. cmt. a.

65. See Menell \& Nimmer, supra note 10, at 949. 
(such as archiving of programming). ${ }^{66}$ Other design changes (for instance, squelching commercial skipping and preventing videotaping of broadcasts for which copyright owners opposed home copying) were not reasonably available and might also have failed the risk-utility tradeoff by dramatically increasing costs or unreasonably impairing fair uses. Therefore, presented with tort theory on the record then available, the Court should have determined that plaintiffs could not prove their RAD theory.

Thus, even under the RAD regime, Sony would not have been subject to indirect liability for the Betamax. It did not engage in concerted conduct with direct infringers. There were no RADs for its device that offered sufficient reductions in risk of (and harm from) infringement to counterbalance the demonstrable and significant loss in legitimate uses of the Betamax device. For that reason, the outcome of the case was correct, even though the test it promulgated was flawed.

\section{The Seeds of Confusion}

In reaching its Sony decision, the Supreme Court turned not to tort law but to patent law. That resolution has produced unnecessary distortion in copyright doctrine. The succeeding Parts of this Article track the deviation and the pressure to hew back to traditional tort principles. Proponents view the Sony decision as the "Magna Carta" of both "product innovation" ${ }^{167}$ and the "technology age." follows of subsequent developments paints Sony as less epochal.

Meanwhile, the transition from the analog age in which the Sony case arose to the current digital age has only made more pressing the question of what standards should govern design of products that can be used to infringe copyrights. For, as of 1984, designers could select from far fewer variables. In today's digital age, geometrically more ways exist to monitor and control products. As Randal Picker suggests, the law should exert every effort to produce optimal results:

We need to focus on the process of product evolution, the choices that designers make regarding their ability to evolve the product in light of evolving use and who should have a stake in controlling that evolution... To be extreme, imagine a product that will create $\$ 10$ million worth of beneficial noninfringing uses and only $\$ 100$ in harmful infringing uses. This is a wonderful product. But if we could

66. The Supreme Court did not directly resolve whether archiving was fair use.

67. See Picker, supra note 4 , at 753.

68. See Litman, supra note 5, at 951-60; Parloff, supra note 5, at 148. 
spend $\$ 5$ for a modified design that would keep the same benefits while eliminating the harmful infringing uses, we should do so. ${ }^{69}$

At the same time, a heavy burden must rest on plaintiffs to show that an alternative design was reasonably foreseeable to product manufacturers whose works are later shown to impinge on copyrights. ${ }^{70}$ The interest of the law should be neither to punish manufacturers for lacking clairvoyance nor to saddle them with all the externalities that have adventitiously ensued from their chosen design; it is simply to encourage responsible behavior at the time when those design decisions are reached.

\section{The Legislative Response to SONY'S "StAPle ARTICLE OF COMMERCE" DOCTRINE}

Sony's staple article of commerce doctrine derives from patent standards immunizing dual-use technology from indirect liability. The doctrine rests on the proposition that dual-use technology should be sacrosanct: So long as a device is suitable for substantial noninfringing use, the law errs on the side of free competition, leaving aggrieved patent owners with recourse against only direct infringers. The Sony Court hitched copyright law to this wagon without assessing (1) Congress's intent in comprehensively reforming the Copyright Act of 1976 just eight years earlier sans any parallel safe harbor; (2) the tort framework that had long undergirded copyright law's liability regime; or (3) the policy considerations (enforcement costs and competition effects) bearing on such transplantation to the copyright system. ${ }^{7}$ This Part examines whether Congress has since clarified the proper test for indirect copyright liability. Although the legislature neither directly endorsed nor repudiated the Sony ruling, its subsequent actions (and inaction) suggest that Congress does not consider dual-use technology to be sacrosanct in the context of copyright law.

\section{A. Royalty and Rental Legislative Initiatives}

The legislative wheels started spinning even before Sony reached the Supreme Court. A day after the Ninth Circuit's decision declaring the Betamax in violation of copyright law, Representative Stanford Parris introduced an amendment to the Copyright Act of 1976 declaring that noncommercial

69. Picker, supra note 4 , at $751-52,766$.

70. See supra Part I.B.

71. We have previously analyzed those pre-1984 issues. See Menell \& Nimmer, supra note 10. The current effort focuses on events that have taken place since the Supreme Court's 1984 ruling. 
home use of a video recorder falls within the fair use defense. ${ }^{72}$ Within the next month, consumer electronics manufacturers formed the Home Recording Rights Coalition (HRRC), a lobby focused on issues surrounding home taping. ${ }^{73}$ By month's end, HRRC had persuaded a bipartisan group of senators to introduce similar legislation and the U.S. Senate convened an exploratory hearing. ${ }^{74}$

Sensing the public outcry over the Ninth Circuit's decision and seeing the momentum building to undo its victory, the Motion Picture Association of America (MPAA) quickly mobilized to get its justification out to the public and its legislative proposals before Congress. The sound recording industry also threw its hat into the legislative arena. Citing rising rates of unauthorized copying through the use of cassette tape recorders, the record companies joined forces with the MPAA. Senator Charles Mathias and Representative Don Edwards introduced amendments that would impose royalties on sales of recording equipment and blank video-audio tapes. ${ }^{75}$ The bill also barred rental, leasing, or lending of a video recording without the copyright owner's permission.

This latter provision threatened to wipe out the burgeoning retail video marketplace. By the early 1980s, the studios were selling a growing segment of their catalog into the video stream of commerce. Several million U.S. households owned VCRs, and the video rental business had become an established part of the landscape. The studios were, however, disappointed by their relatively small share of the revenue from the video marketplace. They identified the first-sale doctrine ${ }^{76}$ - which allows the purchasers of copyrighted works to rent, sell, or otherwise transfer the purchased copy-as the culprit. ${ }^{77}$ If they charged a high price for videos, the market was confined largely to video rental stores, resulting in relatively low sales volume. If they moderated their price, sales increased but much of the value flowed to video retailers who benefited from the lower prices

72. See H.R. 4808, 97th Cong. (1981); Andrew Pollack, Video Recorder Sales Go On, N.Y. TIMES, Oct. 21, 1981, at D5.

73. See Home Recording Rights Coalition, History, http:/www.hrrc.org/index.php?id=47\&subid $=6$ (last visited Sept. 6, 2007).

74. See S. 1758, 97th Cong. (1st Sess. 1981); Press Release, PR Newswire (Nov. 30, 1981), available at http://www.lexis.com.

75. H.R. 5707, 97th Cong. (1982); see Michael Wines, Entertainment Industry Wants Congress to Make a Federal Case of Home Taping, 14 NAT'L J. 813 (1982).

76. See 17 U.S.C. $\$ 109(2000)$. Note that the moniker is imprecise, inasmuch as first sale is not technically a prerequisite to its invocation. See 2 MELVILLE B. NIMMER \& DAVID NIMMER, NIMMER ON COPYRIGHT \$ 8.12[B][1][a] (2006) (stating that a more accurate description would be "first authorized disposition by which title passes").

77. See Home Truths for Hollywood, ECONOMIST, July 30, 1983, at 72. 
while continuing to earn the same rental fees. Efforts to restrict the retailers' activities through contract proved unworkable as retailers resold the tapes, free and clear of restrictions, to other video rental stores, which could then rent them out. The film industry sought to address this problem through an amendment to exclude videos from the first-sale provision. ${ }^{78}$

The Supreme Court's grant of certiorari in Sony relieved some of the pressure on members of Congress to confront such a divisive issue. The battle, however, continued to rage, each camp hiring powerful lobbyists to press its cause on both sides of the legislative aisle. ${ }^{79}$ The net result was stalemate, with no legislation emerging from the respective committees during the 97th Congress.

Versions of both bills reemerged at the beginning of the 98th Congress. ${ }^{80}$ Competing studies and intensive lobbying again produced stalemate on the royalty proposals. By the end of 1984, however, the recording industry had achieved partial success, persuading Congress to exclude sound recordings from the first-sale doctrine. By that time, it became apparent that the rental of phonorecords by record stores posed a threat to the viability of the record industry. Many households owned cassette players that could be patched directly into a phonograph. A growing number of record stores were renting phonorecords for twenty-four to seventy-two hour periods for fees of $\$ 0.99$ to $\$ 2.50$ per disc, often at the same time selling blank audio cassette tapes ${ }^{81}$ Most people obtaining phonorecords by rental did so for the purpose of making audio tape reproductions of the rented material. If this practice became more prevalent, sales of phonorecords by the record companies would be impaired. Indeed, one record store audaciously advertised: "Never, ever buy another record." $\$ 2$ In order to meet this threat to the record industry, Congress adopted the Record Rental Amendment of $1984,{ }^{83}$ amending the first-sale doctrine to bar rental of sound recordings except for nonprofit purposes by nonprofit libraries and educational institutions. ${ }^{84}$

78. See Copyright Draft Faces Major Problems, BroAdCASTING, May 28, 1984, at 64.

79. See Howie Kurtz, Chariots for Hire; The Full-Blown! Multimillion Dollar! Lobbying War! For the Affections of Congress! In Search of Videoland Gold!, WASH. POST, July 4, 1982, at B1.

80. See The Bills Are Back, BROADCASTING, Jan. 31, 1983, at 33.

81. See H.R. REP. NO. 98-987, at 2 (1984).

82. See id.

83. Pub. L. No. 98-450, 98 Stat. 1727 (codified at 17 U.S.C. $\S 109$ (b) (2000).

84. A half-dozen years later, Congress extended the rental ban to computer software. See Computer Software Rental Amendments Act of 1990, Pub. L. No. 101-650, 104 Stat. 5089, 5134-37 (codified as amended at 17 U.S.C. $\$ 109$ (b) (2000)). As compared to the phonorecord situation in 1984, "the evidence is even more compelling in the case of software." H.R. REP. NO. $101-735$, at $8(1990)$ ( $\$ 495$ software rented for $\$ 35)$. 
The film industry's parallel legislative initiative failed for political and substantive reasons. In opposing restrictions on the use of home recording equipment, the HRRC mobilized the growing number of retail rental establishments. ${ }^{85}$ They marshaled evidence that consumers rarely made copies of the videos they rented, instead typically watching them once. They also blunted the argument that rentals displaced sales, which had led to the Record Rental Amendment of 1984; relatively few consumers would pay $\$ 30$ or $\$ 40$ to own a video which they watched only once, whereas the record industry was built on consumers owning a phonorecord which they would listen to over and over again.

After the Supreme Court's Sony decision, it became increasingly apparent that, rather than being harmed, the film industry was deriving a sizable and growing portion of revenue from the sale of prerecorded videotapes. Thus, the royalty-based bailout strategy was not destined to fly. But the industry still held out hope of capturing a greater share of the money flowing into the marketplace by obtaining greater leverage over the retail rental business. A limitation on the first-sale doctrine for prerecorded videos would serve that goal. By this time, though, the HRRC was well positioned to counter this initiative through a true grassroots campaign. Their efforts over the previous two years had mobilized the Video Software Dealers Association, a large and growing nationwide organization, to resist any effort to subject video rentals to the control of copyright owners. ${ }^{86}$ By the end of the 1984, the film industry abandoned its legislative effort in this arena as well.

\section{B. The Audio Home Recording Act}

Nonetheless, the recording industry continued its drive for new legislation. It pressed for the imposition of a royalty on recording equipment and blank tapes. With many households owning cassette recorders, the recording industry urged the adoption of legislation to stem the losses from home taping. ${ }^{87}$ This strategy formed part of a global campaign that ultimately achieved imposition of levies in much of Europe

85. See JAMES LARDNER, FAST FORWARD: A MACHINE AND THE COMMOTION IT CAUSED 222-27 (rev. ed. 1987).

86. See id. at 267-88.

87. See Record Industry Seeks Surcharges on Taping, N.Y. TIMES, Oct. 31, 1985, at C21. 
and Australia. ${ }^{88}$ But with record labels earning healthy returns, Senator Howard Metzenbaum challenged the industry at a 1985 hearing to substantiate its claims of economic threat. ${ }^{89}$ Congress ultimately deferred the issue while asking its Office of Technology Assessment to compile a comprehensive study on the effects of home copying on the record industry. ${ }^{90}$ By 1985, the compact disc (CD) format, offering unprecedented sound quality, was gaining momentum in the marketplace. Record industry profits soared in the next few years as $C D$ technology took off, ${ }^{11}$ weakening the case for imposing levies. The legislative momentum stalled and the proposal died in legislative committees.

Yet, a little more than a year later, the cycle of history started anew. ${ }^{92}$ The sound recording industry again knocked on Congress's door, following announcements that digital audio tape (DAT) technology would soon let home users make flawless copies of digitally encoded CD sound recordings. ${ }^{93}$ The argument for protective legislation was stronger than with cassette tape recordings insofar as DAT technology allowed for perfect copies (no degradation in sound quality across multiple generations of copies). The Recording Industry Association of America (RIAA) played up the specter of rampant piracy bringing the industry to its knees. It contended that it should not have to prove actual losses, holding that common sense dictated that such losses would befall the industry if urgent action were not taken.

The record industry first sought to block entry of such devices into the United States through a one-year moratorium on importation of DAT devices unless they included a computer chip that would block the recording of copyrighted music. ${ }^{94}$ Although this legislation ultimately stalled, threats of litigation forestalled importation of DAT machines, notwithstanding the apparent immunity offered by the Sony decision. But when the inevitable

88. See OfFICE OF TECH. ASSESSMENT, U.S. CONG., COPYRIGHT AND HOME COPYING: TECHNOLOGY CHALLENGES THE LAW 12-35 (1989) [hereinafter OTA HOME COPYING STUDY], available at http://www.wws.princeton.edu/ota/disk1/1989/8910_n.html.

89. See Michael Isikoff, Metzenbaum Wams Record Industry, WASH. POST, Oct. 31, 1985, at E3.

90. See OTA HOME COPYING STUDY, supra note 88.

91. See William K. Knoedelseder, Jr., Record Industry Is Suddenly a Smash Hit; Fueled by Boom in Compact Discs, Firms' Fortunes Have Soared, L.A. TIMES, Oct. 15, 1987, at 1.

92. The parallels extend to Sony Corporation being named as the target defendant. See David Nimmer, On the Sony Side of the Street, 34 Sw. U. L. REV. 205 (2004).

93. See Mark Potts, Music Industry Girds for War Over New Tapes; Digital 'Cloning' Technology Seen as Threat to Record Sales, WASH. POST, July 5, 1987, at H1.

94. See Janet Clayton, U.S. Music Industry, Japanese at Odds; Bill to Limit Sale of Digital Tape Recorders Faces Test, L.A. TIMES, Mar. 25, 1987, at 1. 
importation occurred, the rights holders designated veteran songwriter Sammy Cahn as the plaintiff and once again targeted Sony as the defendant. ${ }^{95}$

The case shaped up along similar lines as the predecessor Betamax case. Sony argued that DAT technology, like Betamaxes and Xerox machines, had substantial noninfringing uses-such as the recording of noncopyrighted works or of copyrighted works with permission of the creators, and home copying of CDs owned by the consumer to play on other devices (space shifting). In fact, given the high cost and quality of these machines, their principal use was likely to be in professional recording studios. The music copyright proprietors sought to distinguish Sony by arguing that, unlike VCR users predominantly engaged in legal time shifting (under the fair use doctrine), rather than building archives of programs for repeat viewing, the primary use for DAT recorders was to build a library of music for repeated listening. Whereas videotaping did not supplant the demand for "factory TV shows" (home receptors of broadcasts), DAT taping threatened to decimate factory sales of record products.

Sony appeared to have the better of the argument inasmuch as, under its own eponymous Supreme Court ruling, it only needed to show that DAT technology was "capable of substantial noninfringing uses." Nonetheless, the parties settled" about a year into the litigation. ${ }^{98}$ The various interest groups hammered out a settlement that became the framework for the Audio Home Recording Act of 1992 (AHRA). ${ }^{99}$ The agreement also reflected a worldwide accord between record companies and hardware manufacturers. ${ }^{100}$ After further negotiations with music publishers, songwriters, and performing rights societies, all parties signed onto a basic methodology ${ }^{101}$ _ "an equitable solution that promises everyone a share in

95. See Cahn v. Sony Corp., No. 90 Civ. 4537 (S.D.N.Y. filed July 9, 1990); John Burgess, Sony Sued Over Digital Recorders; Songwriter, Publishers Seek to Block Sales, WASH. POST, July 11,1990 , at B8.

96. Sony Corp. of Am. v. Universal City Studios, Inc., 464 U.S. 417, 442 (1984).

97. As the mandala of history has continued to revolve, Sony itself has mutated into a motion picture studio. It therefore now finds itself allied with the likes of Disney and Universal, its erstwhile adversaries from the Sony days. See Nimmer, supra note 92.

98. See Stephen Levine, The Digital Duel Could Be Ending; Manufacturers, Music Industry Reach Pact, WASH. POST, July 11, 1991, at B8.

99. See S. REP. NO. 102-294, at 33 (1992) (stating that a "historic compromise" led to the dropping of the lawsuit and the fashioning of a legislative proposal); see also Pub. L. No. 102 563, 106 Stat. 4237 (1992).

100. See H.R. REP. NO. 102-873, pt. 1, at 9 (1992).

101. See id. at 10; S. REP. NO. 102-294, at 32-33; 138 CONG. REC. H9037 (daily ed. Sept. 22, 1992) (statement of Rep. McMillan) ("This is landmark legislation which clears the way for the next generation of home audio recording equipment and it was only worked out after years of negotiation."). 
the benefits of the digital audio revolution." ${ }^{\text {"102 }}$ Congress ultimately enacted the agreement of the affected parties into law. ${ }^{103}$

The AHRA unequivocally bans the production and marketing of a dual-use technology: unrestricted DAT devices. Congress prohibited the importation, manufacture, and distribution of any digital audio recording device that does not incorporate technological controls to block secondgeneration digital copies. ${ }^{104}$ The AHRA limits the viral spread of copies: Consumers are allowed to make "one-off" copies but are prohibited from making copies from copies. ${ }^{105}$ In addition, the AHRA imposes levies on the sale of digital audio recording devices and blank media, ${ }^{106}$ the proceeds of which are divided among copyright owners. ${ }^{107}$ It also affords immunity to home tapers who make copies without commercial motivation. ${ }^{108}$ That immunity applies to both digital and analog recordings. ${ }^{109}$ This law shows that Congress was willing to strike a different balance in the copyright system than in the patent sphere in order to deal with the specter of digital piracy. ${ }^{110}$

102. S. REP. NO. 102-294, at 40 (quoting the president of Tandy Corporation); 138 CONG. REC. H9037 (daily ed. Sept. 22, 1992) (statement of Rep. Lent) ("This compromise bill benefits everyone concerned-the manufacturers, the recording companies and artists, and, most importantly, the consumers.").

103. Fast forwarding, what is the upshot of this legislation? It has proven largely a dead letter, overtaken by technological advance (ripping music onto computer devices and MP3 players). See Nimmer, supra note 14 , at 1331-34.

104. See 17 U.S.C. $\$ 1002$ (a) (2000). For a detailed discussion, see 2 NIMMER \& NIMMER, supra note 76 , at ch. $8 \mathrm{~B}$.

105. 17 U.S.C. $\$ 1002$.

106. 17 U.S.C. $\$ 1004$ (2000 \& Supp. IV 2004).

107. 17 U.S.C. $\$ 1006(2000 \&$ Supp. IV 2004).

108. See 17 U.S.C. $\$ 1008$ (2000).

109. Id.

110. When the sale of a staple article of commerce contributes to infringement of patented technology by third parties, the effects are limited to a single patent or perhaps a cluster of no more than a handful of patents. Simply put, a device that contributes to infringement of a particular chemical patent or group of chemical patents is unlikely to infringe a large number of mechanical, electrical, or other chemical patents. Furthermore, the patent owner will have some ability to identify and pursue potential direct infringers by tracing the marketing patterns for the staple article of commerce. There is little reason to believe that a single staple article of commerce could threaten entire technology industries. By contrast, the distribution of at least some dual-use technologies can threaten the very economic foundation of entire content industries (and even multiple industries). Digital audio tape (DAT) posed a systemic threat to all owners of copyrights in musical compositions and sound recordings by enabling individuals to make perfect copies, which could then be distributed to others who could do the same. The costs of enforcing such rights at the direct infringement level would be prohibitive. Thus, the social and systemic benefits of being able to protect copyrights at the indirect infringement level, rather than at the end-use level, are substantial. 


\section{The Digital Millennium Copyright Act}

\section{Anticircumvention Provisions}

Analogous concerns in the mid-1990s prompted content owners to seek even greater protections against digital piracy. As the Internet became a popular platform for the exchange of information, copyright owners came to see encryption and digital rights management as critical elements in the development of the online marketplace for content. They recognized, however, that such technologies were vulnerable to hacking-unauthorized circumvention of technological protection measures. They argued to Congress that, without such protection, they would be unwilling to release content onto the Internet, which in turn would hamper the adoption of broadband services. ${ }^{111}$ Various other interests-ranging from Internet service providers and telecommunications companies to consumer electronic manufacturers, library associations, computer scientists, and copyright professors - expressed concern about the chilling effects of such an expansion of copyright law upon those who transmit content and wish to make fair use of copyrighted works. ${ }^{112}$

In 1998, Congress responded to these concerns by passing the omnibus Digital Millennium Copyright Act (DMCA). ${ }^{113}$ Of most relevance is its Title I, which prohibits circumvention of technological protection measures and bans trafficking in digital keys. ${ }^{114}$ As explained in the Senate Report:

Due to the ease with which digital works can be copied and distributed worldwide virtually instantaneously, copyright owners will hesitate to make their works readily available on the Internet without reasonable assurance that they will be protected against massive piracy. Legislation ... provides this protection and creates the legal platform for launching the global digital on-line marketplace for copyrighted works. It will facilitate making available quickly and conveniently via the Internet the movies, music, software, and literary works that are the fruit of American creative genius. ${ }^{115}$

111. See S. REP. NO. 105-190, at 8 (1988).

112. See David Nimmer, Appreciating Legislative History: The Sweet and Sour Spots of the DMCA's Commentary, 23 CARDOzO L. REV. 909, 917, 921 n.60, $937 \&$ n.160, 938, 950 (2002) [hereinafter Nimmer, Legislative History]; David Nimmer, A Riff on Fair Use in the Digital Millennium Copyright Act, 148 U. PA. L. REV. 673, 686 n.66, 688 (2000) [hereinafter Nimmer, Riff].

113. See Pub. L. No. 105-304, 112 Stat. 2860 (1998).

114. See 17 U.S.C. $\$ 1201(2000)$.

115. S. REP. NO. 105-190, at 8; see also H.R. REP. No. 105-551, pt. 2, at 23 (1998). 
Like the AHRA, Title I of the DMCA goes beyond traditional copyright protections in order to address the threat of unauthorized reproduction and distribution of copyrighted works in the digital age. But rather than mandating specific technology controls like the AHRA's top-down approach, the DMCA envisions bottom-up protection for technological control measures adopted by copyright owners. As to those technological measures that copyright owners implement to control access to their works (such as encryption governing access to an eBook), §1201(a) prohibits specific acts to circumvent the technological measure. ${ }^{116}$ Simultaneously, it bars the manufacture, importation, trafficking in, and marketing of devices that (1) are primarily designed or produced for the purpose of circumventing a technological measure that effectively "controls access to" a copyrighted work; (2) have only a limited commercially significant purpose or use other than to circumvent such technological protection measures; or (3) are marketed for use in circumventing such technological protection measures. ${ }^{117}$ With regard to technological measures regulating use of a work where access has been lawfully obtained, ${ }^{118} \S 1201$ (b) prohibits not the act of circumvention but only the trafficking in and marketing of circumvention devices. This more limited protection was purportedly designed so as not to impair users' ability to make fair use of content to which they have been given access. ${ }^{119}$

Although it allows circumvention of use controls, the ban on trafficking of circumvention devices (including instructions) puts the means for such access beyond the reach of all but the most technically adept-those possessing the ability to decrypt restricted works. ${ }^{120}$ Moreover, it threatens

116. 17 U.S.C. $\$ 1201(\mathrm{a})(1)(\mathrm{A})$. Circumventing a technological measure means to descramble a scrambled work, to decrypt an encrypted work, or "otherwise to avoid, bypass, remove, deactivate, or impair a technological measures, without the authority of the copyright owner." Id. \$1201(a)(3)(A).

117. Id. \&1201(a)(2).

118. Unfortunately, it is difficult, and at times impossible, to isolate the access prong from the copying prong. See David Nimmer, InacCSSibility, in BENJAMIN KAPLAN ET AL., AN UNHURRIED VIEW OF COPYRIGHT, REPUBLISHED (AND WITH CONTRIBUTIONS FROM FRIENDS) 1, $26 \mathrm{n} .130$ (Iris C. Geik et al. eds., 2005) ("Indeed, it may be that the realities of our digital age are such that any manipulation of copyrighted works could be plausibly styled as implicating both access and a right of the copyright owner, meaning that Congress built its so-called vital distinction on sand.").

119. See H.R. REP. NO. 105-551, pt. 1, at 18-19; Exemption to Prohibition on Circumvention of Copyright Protection Systems for Access Control Technologies, 65 Fed. Reg. $64,556,64,557$ (Oct. 27, 2000) (codified at 37 C.F.R. § 201).

120. See Nimmer, Riff, supra note 112, at 673. 
liability for those who violate its strictures not only in the form of massive damages, ${ }^{121}$ but criminal penalties as well. ${ }^{122}$

Thus, as with the AHRA, Congress in the DMCA unequivocally chose to prohibit trafficking in devices and code that have both infringing and noninfringing uses. Decryption technology can be used to gain access to unprotected works. It also can be used to gain access to a protected work in order to make use of an unprotected aspect or to make noninfringing use of some protected elements. Yet, due to the distinctive enforcement concerns posed by digital technology, Congress chose a more circumscribed path for copyright law than it follows for patent law.

\section{Safe Harbors for Online Service Providers}

Title II of the DMCA is called the Online Copyright Infringement Liability Limitation Act (OCILLA). ${ }^{123}$ OCILLA was adopted in tandem with Title I in order to solve the chicken-and-egg problem here: On the one hand, because of "the ease with which digital works can be copied and distributed worldwide virtually instantaneously, copyright owners will hesitate to make their works readily available on the Internet without reasonable assurance that they will be protected against massive piracy." ${ }^{124}$ Title I of the DMCA responds to that concern. But, on the other hand, having a profusion of copyrighted works available will not serve anyone's interest if the Internet's backbone and infrastructure are sued out of existence for involvement in purportedly aiding copyright infringement. As the legislative history clarifies:

$[W]$ ithout clarification of their liability, service providers may hesitate to make the necessary investment in the expansion of the speed and capacity of the Internet. In the ordinary course of their

121. Statutory damages can rise to $\$ 2500$ for every single act of circumvention or product produced. 17 U.S.C. $\$ 1203$ (c)(3)(A) (2000). Thus, a single copyrighted work can give rise to millions of dollars in statutory damages if enough acts or products occur in relation to it. See id. $\$ 1203(\mathrm{c})(4)$ (trebling those amounts for repeat violators). Those prospects markedly depart from traditional statutory damages. See 17 U.S.C. \$ 504(c)(1) (2000) (setting maximum damages "with respect to any one work," no matter how many times it is infringed).

122. See 17 U.S.C. $\$ 1204$ (2000). The Digital Millennium Copyright Act (DMCA) addresses the many objections and concerns raised by various groups through a complex series of narrow exemptions. They apply to entities as diverse as law enforcement, radio and television broadcasters, libraries, and encryption researchers, and to activities as disparate as the filtering of content to prevent access by minors and protecting personal identifying information. See 17 U.S.C. $\S 1201$ (d), (e), (g)-(i). For commentary about composition of the DMCA, see generally Nimmer, Legislative History, supra note 112, at 909.

123. See Pub. L. No. 105-304, § 201, 112 Stat. 2860 (1998).

124. See supra text accompanying note 115. 
operations service providers must engage in all kinds of acts that expose them to potential copyright infringement liability. For example, service providers must make innumerable electronic copies by simply transmitting information over the Internet. Certain electronic copies are made to speed up the delivery of information to users. Other electronic copies are made in order to host World Wide Web sites. Many service providers engage in directing users to sites in response to inquiries by users or they volunteer sites that users may find attractive. Some of these sites might contain infringing material. In short, by limiting the liability of service providers, the DMCA ensures that the efficiency of the Internet will continue to improve and that the variety and quality of services on the Internet will continue to expand. ${ }^{125}$

OCILLA creates four safe harbors from copyright infringement for which online service providers (OSPs) might otherwise be indirectly liable. ${ }^{126}$ Briefly stated, the four relate to transmitting, ${ }^{127}$ caching, ${ }^{128}$ hosting, ${ }^{129}$ and linking. ${ }^{130}$ Inasmuch as the third in that enumeration is the most elaborated in the statute, it is most illustrative of Congress's intent in drafting this provision. ${ }^{131}$

Prior to the Supreme Court's Sony case, copyright law had already developed an elaborate jurisprudence for determining secondary liability. ${ }^{132}$ To prove vicarious liability, the plaintiff had to demonstrate that the defendant possesses (1) an obvious and direct financial interest in the exploitation of the copyrighted materials; and (2) the right and ability to supervise the infringing conduct. ${ }^{133}$ To prove contributory infringement, the plaintiff had to demonstrate that the defendant, with knowledge of the infringing activity, induced, caused, or materially contributed to the infringing conduct of another. ${ }^{134}$ The innovation of Sony, of course, was to depart from the framework by adopting patent law's staple article of commerce doctrine. ${ }^{135}$

125. S. REP. NO. 105-190, at 8 (1998).

126. The definition of "online service providers" (OSPs) is very broad, extending to traditional Internet service providers (ISPs), see 17 U.S.C. $\$ 512(\mathrm{k})(1)(\mathrm{A})(2000)$, as well as to "a provider of online services or network access, or the operator of facilities therefor," id. $\S 512(\mathrm{k})(1)(\mathrm{B})$.

127. Id. $\S 512(\mathrm{a})$.

128. Id. $\S 512(\mathrm{~b})$.

129. Id. $\$ 512(\mathrm{c})$.

130. Id. $\$ 512(\mathrm{~d})$.

131. See 3 NimMER \& NimMER, supra note 76, § 12B.04.

132. See Menell \& Nimmer, supra note 10, at Part III.B.

133. See Shapiro, Bernstein \& Co. v. H.L. Green Co., 316 F.2d 304, 307 (2d Cir. 1963).

134. Gershwin Publ'g Corp. v. Columbia Artists Mgmt., Inc., 443 F.2d 1159, 1162 (2d Cir. 1971).

135. See Menell \& Nimmer, supra note 10 , at $951,976-80$. 
It is instructive to focus on how Congress treated those building blocks when crafting OCILLA in 1998, fourteen years after the Supreme Court handed down Sony. First, it codified both aspects of vicarious liability, stipulating that an OSP could take advantage of the safe harbor for hosting copyright material only if it "does not receive a financial benefit directly attributable to the infringing activity, in a case in which the service provider has the right and ability to control such activity." ${ }^{136}$ Second, it codified both traditional aspects of contributory infringement. ${ }^{137}$ By contrast, the subject provision pointedly omits any codification of the Sony standard of being capable of substantial noninfringing uses. ${ }^{138}$

Section 512 also shows that Congress knows how to create prospective safe harbors when it deems them necessary. The Sony Court's engrafting of an express statutory safe harbor from the Patent $\mathrm{Act}^{139}$ into the recently enacted comprehensive copyright statute lacking any such provision conflicts with well-established conventions of statutory interpretation intended to preserve the separation of powers. ${ }^{140}$ In looking to other statutes for guidance when interpreting a later-enacted statute, the usual inference to be drawn is the opposite of the Sony majority's conclusion: Because the prior enactment shows that Congress knew how to draft an exclusion, its absence in a laterenacted statute in the same or a related field tends to show that Congress

136. 17 U.S.C. $\$ 512(c)(1)(B)$.

137. The reference to the knowledge element is direct: An OSP can take advantage of the safe harbor for hosting copyright material only if it "does not have actual knowledge that the material or an activity using the material on the system or network is infringing." Id. $\S 512(\mathrm{c})(1)(\mathrm{A})(\mathrm{i})$. The reference to the latter element is more oblique: The entire safe harbor for hosting copyright material arises with respect to something tantamount to "materially contributes to the infringing conduct of another," namely, "the storage at the direction of a user of material that resides on a system or network controlled or operated by or for the service provider." Id. $\$ 512(\mathrm{c})(1)$.

138. See id. $\$ 512$. The closest that the statute comes is in its instructions to courts how to craft injunctions. The Online Copyright Infringement Liability Limitation Act (OCILLA) directs courts to consider "whether implementation of such an injunction would be technically feasible and effective, and would not interfere with access to noninfringing material at other online locations." Id. $\S 512(\mathrm{j})(2)(\mathrm{C})$. But the very structure here shows how far afield of Sony this provision falls. Whereas under the Supreme Court's ruling, the defendant would prevail if it could demonstrate the existence of substantial noninfringing uses, under OCILLA's scheme, the defendant has already lost the liability phase of the case and is being enjoined; only in that context can it ask the court to mitigate the harshness of an injunction by balancing loss of access to noninfringing material when entering an injunction against continued availability of the infringing content.

139. 35 U.S.C. $\$ 271$ (c) (2000).

140. As classically stated by the Supreme Court in pre-Sony decisions: "Our objective in a case [turning on the interpretation of a statute] is to ascertain the congressional intent and give effect to the legislative will." Philbrook v. Glodgett, 421 U.S. 707, 713 (1975). 
did not intend to adopt such a provision. ${ }^{141}$ Although such evidence is not conclusive, the Supreme Court has long considered it to be of significant relevance for both divining congressional intent and respecting the legislature's primacy in the lawmaking arena. ${ }^{142}$ Following this logic, the Court would have been on firm footing had it inferred from the presence of the staple article of commerce safe harbor in the Patent Act of 1952 that Congress knew how to draft such a provision if it wished in enacting the Copyright Act of 1976. By not doing so, the conventional inference would have been that Congress did not intend to adopt the staple article of commerce safe harbor in the copyright context. Congress's later adoption of express OSP safe harbors in copyright law via OCILLA reinforces this logic.

\section{Sony's Vector: The Subsequent Congressional Experience}

Our previous article showed that the Supreme Court was mistaken to impute to Congress, as of 1984 , a desire to calibrate indirect copyright liability by reference to patent law's staple article of commerce doctrine. ${ }^{143}$ The current investigation examines whether Congress's post-1984 handiwork has conformed to that putative goal.

The experience debunks any notion that Congress, regardless of its prior intent, after the Sony decision hitched its star to the staple article of commerce bandwagon. To the contrary, the various amendments canvassed above betray the opposite sensibility.

141. Where there is evidence that Congress "knew how to draft a[n] . . exemption," one should not be read into a statute. City of Chicago v. Envtl. Def. Fund, 511 U.S. 328, 338 (1994) (concluding that an express, codified household waste exception showed that the statute did not "extend the waste-stream exemption to the product of such a combined household/ nonhazardous-industrial treatment facility").

142. See, e.g., St. Martin Evangelical Lutheran Church v. South Dakota, 451 U.S. 772 , 784 n.14 (1981) ("Congress knew how to limit expressly an exemption to the place of employment or the type of work performed."); Transamerica Mortgage Advisors, Inc. v. Lewis, 444 U.S. 11, 20-21 (1979); Blue Chip Stamps v. Manor Drug Stores, 421 U.S. 723, 734 (1975) ("When Congress wished to provide a remedy to those who neither purchase nor sell securities, it had little trouble in doing so expressly."); FTC v. Fred Meyer, Inc., 390 U.S. 341, 356-57 (1968) ("[W]hen Congress wished to expand the meaning of competition to include more than resellers operating on the same functional level, it knew how to do so in unmistakable terms."); Keifer \& Keifer v. Reconstruction Fin. Corp., 306 U.S. 381, 395 (1939) ("To assume that Congress in subjecting these recently created governmental corporations to suit meant to enmesh them in these procedural entanglements, would do violence to Congressional purpose. When it chose to do so, Congress knew well enough how to restrict its consent to suits sounding only in contract, even with all the controversies in recondite procedural learning that this might entail. It did so with increasing particularity in the successive Court of Claims Acts.").

143. See Menell \& Nimmer, supra note 10 , at $980-82$. 
Let us start in the Orwellian year of 1984 itself. That year, Sony interpreted the Copyright Act of 1976 as reflecting an intent that an article that is merely capable of substantial noninfringing use stands outside of redress, even if its use in fact massively infringes. Yet, in that same year, Congress amended the Copyright Act to bar record rentals—notwithstanding that the activity of renting phonograph records plainly is capable of fostering substantial noninfringing activity. ${ }^{144}$ One need simply reflect that patrons of the rental establishment may include people who rent to broaden their musical tastes by sampling a smorgasbord of unknown recordings, in order to determine whether they wish to purchase those albums. ${ }^{145}$

The same dynamic gained even greater force in 1992. Congress that year barred sale of DAT recorders, absent technical modifications to prevent unlimited production of copies, notwithstanding that those DAT recorders were plainly capable of fostering substantial noninfringing activity. ${ }^{146}$ Such noninfringing activity can range from amateur bands producing product for public distribution, to hobbyists producing high-quality recordings of their own shower serenades (or garage jam sessions) for their personal enjoyment, to fans who disdain copying a friend's purchased items but wish to space shift their own recordings from car to condo to vacation house. ${ }^{147}$

Moving forward to 1998 , things get even starker. The anticircumvention features of the DMCA ensnare in civil and criminal liability far more parties than those who actually commit copyright infringement. ${ }^{148}$ Indeed, they extend so far as to bar even paradigmatically unobjectionable conduct, such as helping someone to take advantage of a use that the U.S. Copyright

144. See supra Part II.A.

145. The same considerations apply to the later broadening of the ban on record rental to include barring computer software rental in 1990. See supra note 84 . For, in like measure, one need only reflect that the store is capable of renting to people who wish to broaden their exposure to new applications by sampling a smorgasbord of unknown programs, in order to determine if they wished to purchase them.

146. See supra Part II.B.

147. To elaborate, some purchasers of, say, 2 Live Crew's 1990 s prerecorded audio cassettes would, in a world of unencumbered DAT machines, run off multiple copies of them for the purpose of trading, selling, or otherwise. That activity could constitute copyright infringement. Yet, others, after purchasing a recording of "Nasty as They Wanna Be," might have no greater designs than to listen to the album not only on the car's cassette player, but also on the DAT machine in the bedroom. In this instance, the DAT technology shows itself to be capable of substantial noninfringing use. See RIAA v. Diamond Multimedia Sys., Inc., 180 F.3d 1072, 1079 (9th Cir. 1999) (explaining that to "'space-shift' those files that already reside on a user's hard drive [constitutes] paradigmatic noncommercial personal use").

148. See supra Part II.C.1. 
Office has expressly blessed. ${ }^{149}$ In brief, $\$ 1201$ evinces a sensibility far
different from immunizing those who produce a product that is capable of substantial noninfringing uses. ${ }^{150}$ It places the shoe on the other foot by barring those products, even if so capable, if they are "primarily designed or produced for the purpose of circumventing a technological measure that effectively controls access" to a copyrighted work. ${ }^{151}$ Therefore, notwithstanding pious floor statements ${ }^{152}$ seeking to dispel any suggestion that Sony's staple article of commerce rule was being overturned, ${ }^{153}$ the reality is that the actual legislation sprinted away from the safeguards of that ruling for device manufacturers. ${ }^{154}$

149. See Nimmer, Riff, supra note 112, at 735-37. A provision of $\$ 1201$ directs the U.S. Copyright Office to hold hearings to identify categories of works that, by duly promulgated regulations, will fall outside the anticircumvention framework. If Sally successfully petitions the Copyright Office to exempt works in category $\mathrm{X}$ by regulation published in the Code of Federal Register, then Sally can subsequently hack into $X$ without liability. But if Sally is technically unable to accomplish what the law allows her, and therefore hires Harry to help her solely to undertake that permissible conduct, then Harry is culpable for violating the anticircumvention features. Id.

150. See 17 U.S.C. $\$ 1201(\mathrm{a})(2)$ (2000) (including "any technology, product, service, device, component, or part thereof').

151. Id. $\$ 1201(\mathrm{a})(2)(\mathrm{A})$ (emphasis added). To express the matter with faux mathematical precision, a product could escape liability under Sony if only 10 percent of its capability were noninfringing. See David Nimmer, A Tale of Two Treaties, 22 COLUM.-VLA J.L. \& ARTS 1, 18 (1997) (positing that a 10 percent noninfringing use is "commercially significant"). Yet, the DMCA, by adopting the language of "primarily ... produced," would hold that same product liable even if a full 49 percent of its capability were noninfringing. So, the DMCA is perhaps five times more restrictive than Sony.

152. One congressman remarked: "The original version of the [DMCA] threatened this standard, imposing liability on device manufacturers if the product is of limited commercial value. ... I'm very pleased that the conferees have meaningfully clarified that the Sony decision remains valid law." 144 CONG. REC. 25,812-13 (1998) (remarks of Rep. Klug). Others expressed similar views on the House floor. See 144 CONG. REC. E2136 (Oct. 12, 1998) (remarks of Rep. Bliley). Bruce Lehman, Commissioner of Patents and Trademarks, had previously testified to Congress along the same lines. See WIPO Copyright Treaties Implementation Act and Online Copyright Liability Limitations Act, Hearings on H.R. 2281 and H.R. 2280 Before the Subcomm. on Courts and Intellectual Property of the H. Comm. on the Judiciary, 105th Cong. 62 (1997) (statement of Bruce Lehman, Commissioner of Patents and Trademarks).

153. A different dynamic governs the core ruling whereby Sony validated analog recordings by VCRs of over-the-air broadcasts. Part of the DMCA enshrined that limited ruling into law. See 17 U.S.C. $\$ 1201(\mathrm{k})(1)$. For analysis, see 3 NIMMER \& NimMER, supra note 76, § 12A.07[B].

154. 3 NIMMER \& NIMMER, supra note 76, § 12A.19[B] ("Much more basically, those who manufacture equipment and products generally can no longer gauge their conduct as permitted or forbidden by reference to the Sony doctrine. For a given piece of machinery might qualify as a staple item of commerce, with a substantial noninfringing use, and hence be immune from attack under Sony's construction of the Copyright Act-but nonetheless still be subject to suppression under Section 1201. It is in this sense that enactment of the Digital Millennium Copyright Act leaves Sony technically undisturbed, but still emptied of much of its force in this realm. Equipment manufacturers in the twenty-first century will need to vet their products for compliance with Section 1201 in order to avoid a circumvention claim, rather than under Sony to negate a copyright infringement claim." (footnotes omitted)). 
The other portion of the DMCA is telling for different reasons. In adopting OCILLA's safe harbors for OSPs, Congress was writing on a clean slate. ${ }^{155}$ It could have adopted standards from communications law, from patent law, from the Sony decision (or any other case that it liked), or blazed a new trail into the wilderness. In many regards, Congress adopted that last expedient, introducing a system of notice, takedown, and putback otherwise unprecedented in copyright law. ${ }^{156}$ But in terms of cabining that new system, such that it would not be available to undeserving OSPs, Congress adopted each of the four ingredients for calibrating indirect copyright liability that predated the Sony decision. ${ }^{157}$ Rather than adopting any innovation from Sony in that calculus, Congress demurred. ${ }^{158}$ By this time, it is not difficult to discern that the congressional reaction to the Supreme Court's ruling, far from embracing it, has been to turn its back on it in subsequent amendments to the Copyright Act of 1976.

$* * *$

In short, since 1984, Congress on several occasions has approved legislation that bans or limits products or businesses offering substantial noninfringing uses. Thus, even if the Sony majority had correctly read Congress's will as of the adoption of the Copyright Act of 1976, later amendments evince a sensibility much more in line with the reasonable alternative design framework. $^{159}$ In each of these contexts, Congress opted for policies that balance the interests of promoting new technology with concerns about effective copyright protection.

\section{THE JUDICIAL RESPONSE TO SONY’S "STAPLE ARTICLE OF COMMERCE" DOCTRINE}

Regardless of whether Congress has stiff-armed Sony, courts have had less latitude. From the time that ruling came down in 1984 until the issue returned to the Supreme Court in Metro-Goldwyn-Mayer Studios Inc. v.

155. See supra Part II.C.2.

156. Content owners may provide notice of infringing content, requiring the service provider to take down that content, unless the affected party provides a counternotification of noninfringement, thereby occasioning the provider's putting back the subject content. See 17 U.S.C. $\$ \$ 512(\mathrm{c})(3), 512(\mathrm{~g})(2000)$.

157. See supra Part II.C.2.

158. See supra Part II.C.2.

159. See supra Part I.B. 
Grokster, Ltd. ${ }^{160}$ every court in the United States has been bound, under the rules of stare decisis, to follow its lead when applicable. One would therefore expect to find numerous rulings immunizing defendants whose conduct is capable of fostering substantial noninfringing activity, even if in fact much infringing conduct followed in their wake.

Again, experience confounds expectation. A flood of courts have discussed and applied the Sony decision when calibrating the proper balance of fair use. ${ }^{161}$ By contrast, cases addressing secondary liability have been rare. Between 1984 and 2000, the issue scarcely arose. With the proliferation of peer-to-peer technology in 2000 , however, the tide turned. During those recent years, the staple article of commerce doctrine moved to center stage, as two appellate courts and then the Supreme Court in Grokster directly confronted the application of that rule for the digital age.

\section{A. 1984-2000: Relative Dormancy}

For the first sixteen years following the Sony decision, only a handful of cases directly addressed the applicability of the staple article of commerce rule. Of those, only one found the defense available (and the result of that case was effectively reversed by the DMCA). In the others, the courts seemed to be more influenced by basic tort principles.

The first application of Sony, RCA Records v. All-Fast Systems, Inc. ${ }^{162}$ was handed down eight months after the Supreme Court's ruling. All-Fast Systems operated a retail photocopying service. In addition, it offered a service that allowed customers to duplicate cassette tapes using a Rezound machine. The evidence showed that employees of All-Fast Systems used the Rezound machine to make cassette copies of customers' prerecorded tapes marked with copyright notices. In holding All-Fast Systems liable, the court distinguished Sony on the grounds that the commercial operator-as distinguished from the manufacturer-of a duplicating machine may be liable as a contributory infringer for providing the duplicating facilities to

160. See 545 U.S. 913 (2005); infra Part III.B.3.

161. The fair use aspect of the Sony case has been cited in hundreds of cases. See, e.g., Campbell v. Acuff-Rose Music, Inc., 510 U.S. 569, 577-92 (1994); Harper \& Row Publishers, Inc. v. Nation Enters., 471 U.S. 539, 562 (1985); Am. Geophysical Union v. Texaco, Inc., 37 F.3d 881, 916 (2d Cir. 1994), amended and superseded by 60 F.3d 913 (2d Cir. 1994). It has also been the subject of extensive legal scholarship. See, e.g., William W. Fisher III, Reconstructing the Fair Use Doctrine, 101 HARV. L. REV. 1659 (1988); Pierre N. Leval, Toward a Fair Use Standard, 103 HARV. L. REV. 1105 (1990); Frank Pasquale, Breaking the Vicious Circularity: Sony's Contribution to the Fair Use Doctrine, 55 CASE W. RES. L. REV. 777 (2005); Lloyd L. Weinreb, Fair's Fair: A Comment on the Fair Use Doctrine, 103 HARV. L. REV. 1137 (1990).

162. 594 F. Supp. 335 (S.D.N.Y. 1984). 
private customers and furnishing assistance in the duplicating process. A later case raising similar facts held liable as direct infringers the commercial operators of a Rezound cassette-duplicating machine. ${ }^{163}$ The Sony decision undoubredly dissuaded RCA from suing the manufacturer of the Rezound cassette-copying machine. Yet, in terms of the holding, the Sony safe harbor provided no refuge to the defendants actually sued. Instead, liability attached to those directly involved in the infringing activity. Furthermore, the decision effectively dried up the market for Rezound devices by imposing liability on stores that use them.

The Sony rule next arose, again indirectly, in Vault Corp. v. Quaid Software Ltd. ${ }^{164}$ Plaintiff Vault produced PROLOK, a lockout technology that prevented copies of computer diskettes from operating. Quaid Software produced a product called CopyWrite, which unlocked Vault's protective feature, enabling copies of the encrypted diskettes to run as though they were the original. Vault brought suit against Quaid, claiming that the CopyWrite program contributed to the infringement of copyrighted works. Quaid defended this claim on the ground that its software product served a substantial noninfringing use-allowing purchasers of programs on PROLOK diskettes to make archival copies. ${ }^{165}$ The court recognized the overinclusiveness of the Sony rule:

Software producers should perhaps be entitled to protect their product from improper duplication, and Vault's PROLOK may satisfy producers and most purchasers on this score-if PROLOK cannot be copied by the purchaser onto a CopyWrite diskette without infringing the PROLOK copyright. That result does have appeal, but we believe it is an appeal that must be made to Congress. "[I]t is not our job to apply laws that have not yet been written."

Notwithstanding those policy reservations, the decision held in favor of Quaid. In this instance, therefore, the Sony safe harbor actually exerted real-world significance. Nonetheless, the result was short lived. When Congress later adopted the DMCA,${ }^{167}$ it effectively reversed that decision legislatively by imposing liability on companies trafficking in decryption keys. ${ }^{168}$

163. See RCA/Ariola Int'l, Inc. v. Thomas \& Grayston Co., 845 F.2d 773 (8th Cir. 1988).

164. 847 F.2d 255 (5th Cir. 1988).

165. Id. at 262 (citing 17 U.S.C. $\$ 117(2)$ ).

166. Id. at 266 (quoting Sony Corp. of Am. v. Universal City Studios, Inc., 464 U.S. 417, $456(1984)$;

167. See supra Part II.C.1.

168. See 17 U.S.C. $\$ \$ 1201(a)(2), 1201(b)(1)(2000)$. 
The Eleventh Circuit considered itself bound only to a loose application (if that) of the Sony rule when the issue next arose in 1990. The defendants in Cable/Home Communication Corp. ข. Network Productions ${ }^{169}$ developed, promoted, and distributed computer devices for decrypting encoded pay-per-view television broadcasting made available by the plaintiffs through satellite transmissions. The plaintiffs sued for both direct copyright infringement, based on reproduction and distribution of the plaintiffs' copyrighted computer software in its decryption device, and contributory copyright infringement, based on defendants' customers' unauthorized use of the devices to access plaintiffs' copyrighted subscription television programming. Network Productions defended the contributory infringement claim under the Sony staple article of commerce safe harbor, contending that it

sold the Dealer Demo chip to satellite dish dealers for the purpose of demonstrating programming, that the installation of a socket in the slot containing the U-30 chip facilitated the insertion of a repair or diagnostic chip, and that the Bag-O-Parts kit was a device to "clean up" old video tapes. ${ }^{170}$

In dismissing this contention, the court departed from the letter of the Sony rule: "While these alternative uses may be legitimate, we are not convinced that defendants-appellants used, promoted and sold these devices for any purpose other than to cumpromise the VideoCipher ${ }^{\circledR I I . "}{ }^{171}$ In essence, the court applied a subjective intent-based standard without directly addressing whether the asserted noninfringing uses were "substantial." Although the court's indirect copyright ruling could have been equally well supported under an inducement theory, it is notable that the court did not adhere to the dictates of Sony. Instead, it appears to have imported a tort-based framework, sidestepping the safe harbor, based on evidence of intentional wrongdoing.

The Sony staple article of commerce doctrine did not again arise directly until 1996. ${ }^{172}$ In A\&M Records, Inc. v. Abdullah, ${ }^{173}$ defendant Abdullah operated General Audio Video Cassettes, a company that sold blank audiotapes and duplicating equipment. Although such products

169. 902 F.2d 829 (11th Cir. 1990)

170. Id. at 846 n.30.

171. Id.

172. It arose indirectly, however, in Lewis Galoob Toys, Inc. v. Nintendo of America, Inc., 964 F.2d 965 (9th Cir. 1992). The Ninth Circuit there quoted Sony for the vague desideratum about protecting "society's competing interest in the free flow of ideas, information, and commerce." Id. at 969 . But, for analysis, this case actually relied on the pre-Sony case of Midway Manufacturing Co. v. Artic International, Inc., 704 F.2d 1009, 1013 (7th Cir. 1983).

173. 948 F. Supp. 1449 (C.D. Cal. 1996). 
could certainly be used for noninfringing uses, the court rejected the defendant's Sony defense on three grounds:

First, the Supreme Court developed the Sony doctrine by borrowing a concept from patent law, which provides that the sale of a "staple article or commodity of commerce suitable for substantial noninfringing use" cannot constitute contributory infringement. See 35 U.S.C. \$ 271(c) (1984); Sony at 439-40) [sic]. Arguably, the Sony doctrine only applies to "staple articles or commodities of commerce," such as VCR's, photocopiers, and blank, standardlength cassette tapes. Its protection would not extend to products specifically manufactured for counterfeiting activity, even if such products have substantial noninfringing uses. Second, even if the Sony doctrine does apply to items specifically designed for counterfeit use, Sony requires that the product being sold have a "substantial" noninfringing use, and although time-loaded cassettes can be used for legitimate purposes, these purposes are insubstantial given the number of Mr. Abdallah's customers that were using them for counterfeiting purposes.

Finally, even if Sony protected the defendant's sale of a product specifically designed for counterfeiters to a known counterfeiter, the evidence in this case indicated that Mr. Abdallah's actions went far beyond merely selling blank, time-loaded tapes. He acted as a contact between his customers and suppliers of other material necessary for counterfeiting, such as counterfeit insert cards; he sold duplicating machines to help his customers start up a counterfeiting operation or expand an existing one; he timed legitimate cassettes for his customers to assist them in ordering time-loaded cassettes; and he helped to finance some of his customers when they were starting out or needed assistance after a police raid. Therefore, even if Sony were to exonerate Mr. Abdallah for his selling of blank, time-loaded cassettes, this Court would conclude that Mr. Abdallah knowingly and materially contributed to the underlying counterfeiting activity. ${ }^{174}$

This excerpt reads the Sony precedent narrowly. The district court's conclusion that Sony's "protection would not extend to products specifically manufactured for counterfeiting activity, even if such products have substantial noninfringing uses" subordinates the staple article of commerce doctrine in a manner not present on the face of the Sony opinion, in order to ensnare what it perceived to be the intentional aiding and abetting of

174. Id. at $1456-57$. 
counterfeiting activities. Thus does this opinion avoid an expansive reading of Sony whereby a "bad actor" would escape liability.

Mention should also be made that West Publishing Company, as a copyright holder in the role of declaratory defendant, unsuccessfully attempted to invoke the staple article of commerce doctrine in Matthew Bender $\mathcal{E}$ Co. v. West Publishing Co. ${ }^{175}$ The primary holding in that case was that declaratory plaintiff Matthew Bender did not infringe copyright by reproducing stars corresponding to the pagination of West's reporters of judicial opinions. ${ }^{176}$ In so ruling, the Second Circuit noted that Bender's products have "overwhelming, noninfringing uses," thereby precluding Bender's liability as a contributory infringer. ${ }^{177}$ Of course, those overwhelming uses would have produced the identical result as well under the standard articulated by the Sony dissenters (and likewise under the RAD framework urged herein), so this is not a case in which the staple article of commerce doctrine itself furnished the ratio decidendi.

$* * *$

In sum, during its first sixteen years, the Sony ruling produced victory for only a single defendant who relied on its staple article of commerce doctrine in defense of a copyright infringement claim. Those who claimed to fall within its scope instead found application of the doctrine avoided, to their detriment. Even the one defendant who prevailed under the doctrine did so in a context that Congress later repudiated.

\section{B. Post-2000: "Staple Article of Commerce" Doctrine Takes Center Stage}

When Congress enacted the DMCA in late 1998, few imagined that the copyright system would be completely unprepared for the digital challenges

175. 158 F.3d 693 (2d Cir. 1998), cert. denied, 526 U.S. 1154 (1999). Disclosure should be made that one of the current co-authors represented Matthew Bender \& Co. in that case.

176. Id. at 702-06.

177. Id. at 706-07. The court explained:

West has a thin copyright in its compilations, which it seeks to leverage to protect its pagination (an element of its compilation that is unprotected altogether) and thereby to foreclose (or draw royalties from) CD-ROM products that might be used incidentally to replicate West's arrangement of cases, but that have substantial, predominant and noninfringing uses as tools for research and citation.

Id. at 707 (emphasis added). 
that would unfold when the millennium turned. ${ }^{178}$ The amount of content available over the Internet took a quantum leap in late 1999 with the introduction of Napster's peer-to-peer network technology. This technology vastly expanded the effective storage and exchange capacity of the Internet by enabling computer users running Napster's software to search the computer drives of thousands of other users for files encoded in the MP3 compression format commonly used for music files. Napster's server contained the labels of MP3 files, typically some combination of band and song titles, which could be searched by Napster users. Napster became the fastest adopted software application in the history of computer technology, attaining seventy-five million users within its relatively brief period of operation. ${ }^{179}$

Major record labels, composers, music publishers, and some recording artists attacked the problem by suing Napster for indirect copyright infringement. The alternative of suing individuals using the software would have been time consuming, expensive, and less effective in stemming the unauthorized distribution occurring through the Napster network. Although Napster did not engage in any direct acts of copying or distributing copyrighted works of others, its software in combination with its centralized indexing function facilitated rampant unauthorized distribution of copyrighted works. The district court issued a preliminary injunction ${ }^{180}$ and the Ninth Circuit ultimately affirmed Napster's liability. ${ }^{181}$

After its success against Napster, the recording industry turned its attention to other peer-to-peer services offering similar functionality. In re Aimster Copyright Litigation ${ }^{182}$ targeted a service that piggybacked on America Online (AOL) Instant Messenger, allowing simultaneous users of an AOL chat room to swap files. The Seventh Circuit rejected Aimster's construction of Sony

178. Even after Napster was enjoined, "millions of people in the United States and around the world continue to share digital .mp3 files of copyrighted recordings using P2P computer programs such as KaZaA, Morpheus, Grokster, and eDonkey." RIAA v. Verizon Internet Servs., Inc., 351 F.3d 1229, 1231 (D.C. Cir. 2003). One recording artist testified to Congress "that whether we like it or not, Napster has changed everything." Online Entertainment and Copyright Law: Coming Soon to a Digital Device Near You: Hearing Before the Committee on the Judiciary, 107th Cong. 14 (2001) (statement of Don Henley, Recording Artist, Cofounder, Recording Artists Coalition).

179. See A\&M Records, Inc. v. Napster, Inc., 114 F. Supp. 2d 896, 902 (N.D. Cal. 2000), affd in part, rev'd in part, 239 F.3d 1004 (9th Cir. 2001) ("Approximately 10,000 music files are shared per second using Napster, and every second more than 100 users attempt to connect to the system.").

180. Id. at 927 .

181. Id. at 1029 (affirming the determination of liability, and staying application of the preliminary injunction until modified by the district court). For a critique of the Ninth Circuit's analysis, see Nimmer, supra note 14 , at 1355-62.

182. 177 F. Supp. 2d 1380 (J.P.M.L. 2001). 
as immunizing the seller of a product used solely to facilitate copyright infringement if it were capable in principle of noninfringing uses. ${ }^{183}$

But the juggernaut faltered with the next litigation. In Grokster, both the district court and the Ninth Circuit rigorously applied Sony's staple article of commerce doctrine to immunize peer-to-peer services from liability. ${ }^{194}$ The disparity between Aimster and Grokster set the stage for the Supreme Court to revisit the question of indirect liability under the Copyright Act of 1976 for the first time since Sony. Its resulting ruling in Grokster reversed, but at the same time created a new wrinkle in Sony jurisprudence. ${ }^{155}$

\section{The Napster Case}

Napster's peer-to-peer technology involved two principal dimensions: the software that consumers downloaded from Napster's servers and the centralized indexing service running on Napster's servers. Napster's software scanned users' hard drives to identify all files encoded in the MP3 format commonly used for compressed music. It then transmitted the file names (but not the music files themselves) to Napster's central server, which stored the names along with a link to the user's Internet protocol (IP) address. Most users labeled their music files with song titles, often accompanied by the recording artist's name. Napster users conducted searches of the files of other users by submitting a query to Napster's central server. That server, in turn, returned a list of the locations of all files featuring the search terms. The requesting user then downloaded the file directly from another Napster user's computer, using a standard Internet transmission protocol without any further involvement of Napster. The infringing file never crossed Napster's server, thereby insulating Napster from any claim of direct copyright infringement. But pursuing individual Internet users for direct infringement would have been difficult, expensive, and of limited efficacy. Given the rampant unauthorized distribution of copyrighted musical compositions and sound recordings facilitated by Napster, music publishers, sound recording companies, and artists brought suit against Napster under an indirect infringement theory. ${ }^{186}$ Napster responded with the staple article of commerce defense, emphasizing the

183. In re Aimster Copyright Litig., 334 F.3d 643 (7th Cir. 2003), cert. denied sub nom., Deep v. RIAA, 540 U.S. 1107 (2004).

184. 259 F. Supp. 2d 1029, 1046 (C.D. Cal. 2003), aff d, 380 F.3d 1154 (9th Cir. 2004).

185. Metro-Goldwyn-Mayer Studios Inc. v. Grokster, Ltd., 545 U.S. 913 (2005).

186. See A\&M Records, Inc. v. Napster, Inc., 114 F. Supp. 2 d 896 (N.D. Cal. 2000), aff'd in part, rev'd in part, 239 F.3d 1004 (9th Cir. 2001). 
use of its technology to exchange works in the public domain, songs for which the copyright owners consented, and the promotion of new artists. It fashioned its defense along the same lines as Sony Corporation, emphasizing the general purpose nature of its product and the fact that some artists consented to having their works exchanged through the Napster network.

The district court distinguished between the scenario in Sony, in which "the only contact between Sony and the users of the Betamax ... occurred at the moment of sale," ${ }^{187}$ and its own case, in which "Napster, Inc. maintains and supervises an integrated system that users must access to upload or download files." ${ }^{188}$ The judge rejected the notion that Napster had the potential to be used for substantial noninfringing uses, ${ }^{189}$ concluding that 'Napster's primary role of facilitating the unauthorized copying and distribution [of] established artists' songs renders Sony inapplicable."190

Although ultimately likewise rejecting Napster's defense under this doctrine, the Ninth Circuit parted company with the reasoning below. ${ }^{191}$ It rejected the district court's focus on "current uses, ignoring the system's capabilities." Regardless of present utilization, the Napster service was "capable of commercially significant noninfringing uses." 193 One need simply imagine its New Artists Program vaulting young talent to a popularity rivaling Britney Spears and Eminem. But the court distinguished between Napster's architecture and its operation of the system whereby users exchanged songs. ${ }^{194}$ It held the former akin to manufacturing a VCR and declined to "impute the requisite level of knowledge to Napster merely because peer-to-peer file sharing technology may be used to infringe plaintiffs' copyrights." ${ }^{195}$ It held the latter, by contrast, outside the staple article of commerce doctrine. The distinction recognizes that a product which is manufactured and sold may qualify for immunity under Sony, but a service requiring ongoing support and involvement may not.

187. Sony Corp. of Am. v. Universal City Studios, Inc., 464 U.S. 417, 438 (1984).

188. A\&M Records, 114 F. Supp. 2d at 917.

189. Immediately after invoking "potential non-infringing uses of Napster," the court confined its attention to the present: "[T]he New Artist Program may not represent a substantial or commercially significant aspect of Napster." Id.

190. Id.

191. A\&M Records, Inc. v. Napster, Inc., 239 F.3d 1004, 1021.

192. Id. ("Consequently, the district court placed undue weight on the proportion of current infringing use as compared to current and future noninfringing use.").

193. Id. (quoting Sony Corp. of Am. v. Universal City Studios, Inc., 464 U.S. 417, 442-43 (1984) (emphasis added by Ninth Circuit)).

194. Id. at 1020 .

195. Id. at 1020-21. 
Accordingly, this case continues the almost unbroken tally from the first sixteen years of Sony's existence. Once again, the targeted defendant failed to escape liability despite its invocation of Sony's staple article of commerce doctrine. ${ }^{196}$

\section{The Aimster Case}

In the wake of Napster's rise, a clever programmer developed software to combine AOL Instant Messenger's technology with file sharing. ${ }^{197}$ Unlike Napster, Aimster's peer-to-peer technology did not rely upon a central server to facilitate the sharing of files. As explained by the Seventh Circuit:

Someone who wants to use Aimster's basic service for the first time to swap files downloads the software from Aimster's Web site and then registers on the system by entering a user name (it doesn't have to be his real name) and a password at the Web site. Having done so, he can designate any other registrant as a "buddy" and can communicate directly with all his buddies when he and they are online, attaching to his communications (which are really just e-mails) any files that he wants to share with the buddies. All communications back and forth are encrypted by the sender by means of encryption software furnished by Aimster as part of the software package downloadable at no charge from the Web site, and are decrypted by the recipient using the same Aimster-furnished software package. If the user does not designate a buddy or buddies, then all the users of the Aimster system become his buddies; that is, he can send or receive from any of them.

Users list on their computers the computer files they are willing to share. (They needn't list them separately, but can merely designate a folder in their computer that contains the files they are willing to share.) A user who wants to make a copy of a file goes online and types the name of the file he wants in his "Search For" field. Aimster's server searches the computers of those users of its software who are online and so are available to be searched for files they are willing to share, and if it finds the file that has been requested it instructs the computer in which it is housed to transmit the file to the recipient via the Internet for him to download into his computer. Once he has done this he can if he wants make the file available for sharing with other users of the Aimster system by listing it as explained above. ${ }^{198}$

196. See supra Part III.A.

197. See Alec Klein, Going Napster One Better: Aimster Says Its File-Sharing Software Skirts Legal Quagmire, WASH. POST, Feb. 25, 2001, at A1.

198. In re Aimster Copyright Litig., 334 F.3d 643, 646 (7th Cir. 2003), cert. denied sub nom., Deep v. RIAA, 540 U.S. 1107 (2004). 
Music copyright owners brought suit against John Deep, Aimster's founder and chief operator, ${ }^{199}$ and the corporations controlling Aimster, alleging vicarious and contributory copyright infringement. The defendants asserted the Sony staple article of commerce defense, emphasizing two features of the Aimster software design: its versatility in enabling users to exchange any type of file, and its lack of control over users' activities.

Although Judge Posner saw the case as centering on the Sony decision, he effectively sidestepped the staple article of commerce doctrine. Rather, he deliberated over whether the Sony rule should be read to control the very different setting presented by peer-to-peer technology:

Although Sony could have engineered its video recorder in a way that would have reduced the likelihood of infringement, as by eliminating the fast-forward capability, or, as suggested by the dissent, [Sony Corp. of Am. v. Universal City Studios, Inc., 464 U.S. 417,] 494, by enabling broadcasters by scrambling their signal to disable the Betamax from recording their programs (for that matter, it could have been engineered to have only a play, not a recording, capability), the majority did not discuss these possibilities and we agree with the recording industry that the ability of a service provider to prevent its customers from infringing is a factor to be considered in determining whether the provider is a contributory infringer. Congress so recognized in the Digital Millennium Copyright Act ... ${ }^{200}$

Judge Posner attempted to balance several competing concerns_-including the Sony decision's purpose of insulating providers of dual-use technology from potentially crushing liability, as well as the implications of the design choices underlying the Aimster product. Notwithstanding "the possibility of substantial noninfringing uses of the Aimster system"201-a complete defense if Sony's articulation of that standard is accepted literally-the defendant's case foundered on its inability to offer "any evidence that its service has ever been used for a noninfringing use, let alone evidence concerning the frequency of such uses."202 Judge Posner's logic hearkens back to the "primary use" standard invoked in Justice Blackmun's Sony dissent. ${ }^{203}$

199. See Wikipedia, Madster, http://en.wikipedia.org/wiki/Madster (last visited June 4, 2007) (chronicling Aimster's short, but dramatic, history).

200. In re Aimster, 334 F.3d at 648 (citing Sony Corp. of Am. v. Universal City Studios, Inc., 464 U.S. 417 (1984)).

201. Id. at 652 .

202. Id. at 653 .

203. See Menell \& Nimmer, supra note 10 , at 984 . 
Moreover, he resolved contributory infringement based on a tort model reminiscent of the "least cost avoider" ${ }^{\text {204 }}$ :

Even when there are noninfringing uses of an Internet file-sharing service, moreover, if the infringing uses are substantial then to avoid liability as a contributory infringer the provider of the service must show that it would have been disproportionately costly for him to eliminate or at least reduce substantially the infringing uses. Aimster failed to make that showing too, by failing to present evidence that the provision of an encryption capability effective against the service provider itself added important value to the service or saved significant cost. Aimster blinded itself in the hope that by doing so it might come within the rule of the Sony decision. ${ }^{205}$

This decision condemned Aimster's "willful blindness" as tantamount to guilty knowledge ${ }^{206}$ and refused to accord it relief based on its "ostrich-like refusal to discover the extent to which its system was being used to infringe copyright." ${ }^{207}$ That 2003 ruling from the Seventh Circuit, like the 2001 Napster ruling from the Ninth Circuit, simply extended the trend inaugurated right after the Supreme Court's 1984 ruling. Again in these examples, no targeted defendant escaped liability by invoking Sony's staple article of commerce doctrine. By this time, that track record had lasted almost two decades.

\section{The Grokster Case}

During the two years in which the Napster litigation unfolded, several new generations of file-sharing technology evolved, ranging from the highly decentralized Gnutella platform to various intermediate architectures using a supernode structure. ${ }^{208}$ Internet users quickly migrated to these new architectures. Morpheus, $\mathrm{KaZaA}$, and Grokster, all based on the supernode architecture, attracted the most users. ${ }^{209}$ The supernode architecture creates a pyramidal computer network for accessing files. Each computer within the system communicates directly with other peers, with the main system

204. See id.

205. In re Aimster, 334 F.3d at 653.

206. Id. at 650 .

207. Id. at 655 .

208. See David P. Anderson \& John Kubiatowicz, The Worldwide Computer, ScI. AM., Mar. 2002, at 40-47; Napster Eclipsed by Newcomers, WIRED, Sept. 6, 2001, http://www.wired.com/techbiz/ media/news/2001/09/46596.

209. See Brad King, While Napster Was Sleeping, WIRED, July 24, 2001, http://www.wired.com/ gadgets/portablemusic/news/2001/07/45480; Melanie Warner, The New Napsters, FORTUNE, Aug. 12, 2002, at 115, available at http://money.cnn.com/magazines/fortune/fortune_archive/2002/08/ 12/327036/index.htm. 
server functioning solely to provide software to participate in the network and providing the Internet address of another computer in the network that functioned as a supernode, a proxy server that relayed queries and responses within the network. Once in communication with a supernode, users could submit queries to locate files with specified search terms. The system would then return the addresses of all computers with files containing the search term. The requesting computer user could then download the files with the click of a button. These new peer-to-peer networks were more versatile than Napster, allowing access to any type of file (not just MP3 formats).

Therefore, even after prevailing in the Napster case, the record labels found themselves back where they started. These services "marketed themselves as 'the next Napster.",210 According to Webnoize, a company that measures Internet traffic, the top four file-sharing systems were used to download more than three billion sound recording files in August 2001. ${ }^{211}$ The record labels sued the operators of the Morpheus, KaZaA, and Grokster services in October 2001.

The defendants filed a motion for summary judgment on the grounds that their software had substantial noninfringing uses and was outside of their control. Unlike Napster, their file server contained only the addresses of computers (and not file names). Also unlike Napster, their technology allowed searching for any type of file, thereby increasing the range of usesincluding noninfringing uses. Users could download Shakespeare and other public domain works, scientific data, federal government documents, and many other works that were not protected by copyright. They could also download copyrighted works for which distribution was authorized. The plaintiffs countered that the predominant use (approximately 90 percent) of these systems was to share copyrighted works. ${ }^{212}$

Although "not blind to the possibility that Defendants may have intentionally structured their businesses to avoid secondary liability for copyright infringement, while benefiting financially from the illicit draw of their wares," the district court granted summary judgment in favor of the defendants. ${ }^{213}$ That ruling is revolutionary-it marks the only time (other than the legislatively overturned Vault ruling) that any defendant had

210. Metro-Goldwyn-Mayer Studios Inc. v. Grokster, Ltd., 259 F. Supp. 2d 1029, 1036 (C.D. Cal. 2003), aff'd, 380 F.3d 1154 (9th Cir. 2004), vacated, 545 U.S. 913 (2005).

211. See Brad King, File Trading Sites in Crosshairs, WIRED, Oct. 3, 2001, http://www.wired.com/ gadgets/portablemusic/news/2001/10/47296.

212. Grokster, 259 F. Supp. 2d at 1036-37.

213. Id. at 1046. 
successfully invoked Sony's staple article of commerce doctrine. ${ }^{214}$ But (again like Vault), it also proved short lived ${ }^{215}$-even though initially affirmed. ${ }^{216}$ Judge Thomas of the Ninth Circuit upheld the undisputed finding that the peer-to-peer software at issue was capable of substantial noninfringing uses. ${ }^{217}$ The Ninth Circuit held defendants not culpable for contributory infringement, in light of the architecture of their decentralized system by contrast to Napster's centralized set of servers. ${ }^{218}$ Rejecting Aimster, ${ }^{219}$ it disallowed any separate "blind eye" theory of liability. ${ }^{220}$

If the story ended there, then Sony's staple article of commerce doctrine, though born moribund to all appearances, would have picked up vitality in its teenage years, ultimately to emerge victorious. For the two lower court Grokster rulings breathed life into protection for that which is merely capable of substantial noninfringing use, though in fact employed predominantly to infringe. It is therefore all the more noteworthy that a unanimous Supreme Court vacated both those rulings. That last decision merits its own close investigation. In the third and final installment to this series, we place that decision under a magnifying glass. ${ }^{221}$ For current purposes, all that need be noted is that, just like Sony, Grokster sent copyright law into a new direction by importing a doctrine of patent law in order to reverse the Ninth Circuit ruling below. ${ }^{222}$ The end result, once again, was to frustrate the position of the litigant who relied on Sony furnishing the governing standard.

The experience of the Grokster case on remand is telling. Plaintiffs at that juncture were able to prevail strictly on the theory that defendants had actively induced third parties to engage in infringing conduct, without the need to delve into the finer points of Sony's exegesis. ${ }^{223}$ Likewise, the same plaintiffs, when targeting the Betamax's great-grandchild-a remote-storage digital video recorder (DVR) system-simply claimed that its manufacturer

214. See supra Part III.A.

215. See supra Part III.A.

216. See Metro-Goldwyn-Mayer Studios, Inc. v. Grokster, Ltd., 380 F.3d 1154 (9th Cir. 2004), vacated, 545 U.S. 913 (2005).

217. Id. at 1161 .

218. Id. at 1163 .

219. Id. at 1162 n.9.

220. Id. at 1166 .

221. See Peter S. Menell \& David Nimmer, A Direct Analysis of Indirect Copyright Liability (or, How Grokster Should Have Come Out) (forthcoming).

222. In Sony, the Court imported 35 U.S.C. $\$ 271$ (c). 464 U.S. 417, 435 (1984). Two decades later, Grokster imported 35 U.S.C. $\$ 271$ (b). 545 U.S. 913,935 n.10 (2005).

223. See Metro-Goldwyn-Mayer Studios, Inc. v. Grokster, Ltd., 454 F. Supp. 2d 966 (C.D. Cal. 2006). 
engaged in direct copyright infringement, thereby likewise saving themselves headaches rooted in Sony's legacy. ${ }^{224}$

\section{Sony's Vector: The Subsequent Judicial Experience}

The legacy of Grokster is that both plaintiffs and defendants, for their own separate reasons, have increasingly avoided hanging their hats on the protean Sony doctrine. To avoid being confronted with evidence of noninfringing use, plaintiffs instead have increasingly alleged inducement of copyright infringement, or else have tried to style defendants as direct infringers, thereby eliding the entire inquiry into indirect liability. For their part, defendants have focused on the immunity afforded by the safe harbor for OSPs added via the $\mathrm{DMCA}^{225}$ with like design of rendering Sony of no moment.

Like the previous investigation showing how Congress has turned its back on Sony, the instant roundup shows that courts have spun pirouettes to avoid the need to follow Sony's lead. The exceptions were Vault, which Congress overturned, and the lower two Grokster rulings, which the Supreme Court reversed.

Because the peer-to-peer cases have loomed so large in this field, a few more words should be added about the dynamic of court rulings. ${ }^{226}$ Both Napster and Aimster defended themselves as straightforward applications falling within Sony's safe harbor. In response to their claims that their peer-to-peer technology was capable of substantial noninfringing use, the courts in each instance ultimately determined that the safe harbor did not shield their respective defendants from liability. In the process, the courts distorted copyright law in confusing and inconsistent ways. Still, these rulings exerted little effect. Any curtailment of unauthorized distribution of copyrighted works through peer-to-peer technology was short lived as new peer-to-peer software enterprises, built upon less-centralized software architectures, entered the market. These peer-to-peer technologies posed even greater exposure for copyright owners than Napster and Aimster because they were not limited to the distribution of music files. The new services

224. See Twentieth Century Fox Film Corp. v. Cablevision Sys. Corp., 478 F. Supp. 2d 607, 618 (S.D.N.Y. 2007) ("Cablevision's reliance on Sony is misguided. . . . [A]part from their time-shifting functions, the RS-DVR [Remote-Storage Digital Video Recorder] and the VCR have little in common, and the relationship between Cablevision and potential RS-DVR customers is significantly different from the relationship between Sony and VCR users.").

225. See supra Part II.C.2.

226. See supra Part III.B. 
allowed for the distribution of just about any type of file-including movies, software, photographs, and eBooks. Unlike Napster, which operated during its brief existence without any direct revenue model, many of the second generation peer-to-peer system enablers designed their systems to deliver advertisements (in the form of banners, pop-ups, and other text boxes that appear on users' computer screens). Using the Sony staple article of commerce doctrine as a guide, they designed their technology in such a way as to limit their control over the peer-to-peer network, yet nonetheless derive substantial advertising revenue from the network's use.

But, in the end, that reliance on Sony proved ill-founded. For the Supreme Court reacted to a successful invocation of the staple article of commerce doctrine that immunized a defendant from liability by reaching into its bag of tricks and inventing a new reason that those defendants should be liable. ${ }^{227}$

At the end of the day, no final judgment that has withstood congressional action has ever applied Sony to immunize from liability a defendant whose product, albeit capable of substantial noninfringing use, was in fact used more for the purpose of committing copyright infringement. Instead of applying the staple article of commerce doctrine as formulated, courts instead have contorted their analyses to find liable those whose conduct appears blameworthy, even if that behavior nominally would fall within Sony's safe harbor. Thus, far from constituting the Magna Carta of the digital age, ${ }^{228}$ Sony has proven to be shaky and vague Supreme Court precedent. Its legacy speaks more to the precepts of legal realism than the vitality of copyright's staple article of commerce doctrine.

\section{THE MARKET'S Response to SONY'S “STAPLE ARTIClE OF COMMERCE" DOCTRINE}

Still, the judicial dormancy of, and congressional antipathy to, Sony's staple article of commerce doctrine does not mean that the decision has lacked significance. Part of the reason that the Sony indirect liability rule received relatively little play in the courts is that content owners exercised care in choosing which fights to pick. Both the Sony case and the MPAA's failure to obtain video rental legislation taught Hollywood valuable lessons about the importance of consumer interests in the courts and Congress. ${ }^{229}$

227. As noted above, see supra note 222 , Grokster innovated by being the first decision to import 35 U.S.C. $\$ 271$ (b) as the basis to construe the Copyright Act of 1976.

228. See supra text accompanying note 68 .

229. See LARDNER, supra note 85 , at 287 . 
At the same time, consumer electronics companies now possessed a liability shield, lobbying know-how, grassroots organizing experience, and an "inside the Beltway" presence to countervail Hollywood's legislative might.

It would be a gross overstatement, however, to suggest that the Sony safe harbor settled the battle between content owners and technology companies. This last inquiry examines what might be called the real-world "shadow" ${ }^{230}$ of the Sony staple article of commerce safe harbor.

\section{A. Audiocassettes}

At the same time that the Sony case was wending its way through the courts, the market for home cassette recording equipment was taking off, generating fear among copyright owners about widespread home copying of sound recordings and resulting displacement of sales. Several factors weighed against direct litigation, including the fact that record companies earned substantial revenue from the sale of prerecorded audio cassettes, ${ }^{231}$ and that cassette recording devices had substantial noninfringing usesfrom recording a baby's first words to taking dictation to recording telephone messages on cassette-based answering machines. Although the economic effects of audio home taping (where archiving was prevalent) differed from the patterns of video home taping (predominantly time shifting with rerecording), the Sony case undoubtedly stood as a major obstacle to suing manufacturers of cassette devices or blank tapes. But it certainly did not take the issue off the table.

Record companies took their complaints to Capitol Hill, arguing that cassette recording technology threatened the industry and pressing for levies on recording devices and blank media that could be used to stanch the losses due to home recording. Prior to serving as chairman of the Federal Reserve Bank, Alan Greenspan, as chairman and president of an economic consulting firm, testified as the recording industry's primary consultant:

At present... severe economic damage [is being done] to the property rights of owners of copyrights in sound recordings and musical compositions... under present and emerging conditions, the industry

230. Cf. Robert H. Mnookin \& Lewis Kornhauser, Bargaining in the Shadow of the Law: The Case of Divorce, 88 YALE L.J. 950 (1979).

231. In 1984, cassettes surpassed albums as the preferred format of prerecorded music, accounting for over 55 percent of the industry's total revenues. See Is Horowitz, RIAA Figures: Cassettes Paced a Record '84, BillboARD, Apr. 13, 1985, at 1. 
simply has no out... Unless something is done to respond to the problem, the industry itself is at risk. ${ }^{232}$

The industry took particular umbrage at the introduction of dual-deck cassette recorders a short time after this testimony. ${ }^{233}$ Stanley Gortikov, president of the RIAA, denounced these murderous machines:

Dual-cassette recorder[s] . . . exist primarily to duplicate copyrighted prerecorded music cassettes--sometimes at two, four and even six times normal speed .... The problem has reached crisis proportions.... Are we to stand by passively and watch the greatest musical creative community in the world strangle to death from newer and newer generations of copyright killer machines? But the worst is yet to come. Here is Japan's newest weapon-a triple-deck cassette machine. ${ }^{234}$

As noted earlier, ${ }^{235}$ however, opposition from consumer electronics companies and other groups defeated proposed antitaping legislation. When record labels could not show any diminished revenues, support for the legislation dissipated. But legislation targeting DAT technology became law, although not without some litigation fuel, as the next discussion shows.

\section{B. Digital Audio Tape}

As previewed above ${ }^{236}$ the recording industry vowed to block introduction of DAT technology for home use into the United States unless restrictions were imposed to prevent unauthorized distribution of copyrighted works. Taking a page from Jack Valenti's vilification of the VCR, ${ }^{237}$ Stanley Gortikov characterized this technology as "an assassination in the making" with "the targeted victim the world's music industry."238 After three years, negotiations between the consumer electronics and music industries appeared to reach accord in 1989 around the requirement that DAT devices would contain a computer that prevented second-generation

232. Video and Audio Home Taping: Hearing on S. 31 Before the Subcomm. on Patents, Copyrights and Trademarks of the S. Comm. on the Judiciary, 98th Cong. 232 (1983) (statement of Alan Greenspan).

233. See Jon Pareles, Royalties on Recorders and Blank Audio Tapes, N.Y. TIMES, Nov. 21, 1985 , at C34.

234. Home Audio Recording Act: Hearings on S. 1739 Before the Subcomm. on Patents, Copyrights and Trademarks of the S. Comm. on the Judiciary, 99th Cong. 90 (1985) (statement of Stanley Gortikov, President, Recording Industry Association of America).

235. See supra Part II.A.

236. See supra Part II.B.

237. See supra note 25 .

238. Richard Harrington, RIAA Moving to Washington, WASH. POST, Sept. 8, 1986, at C2. 
copies, ${ }^{239}$ but the music industries later backed out. Sony, which had already been selling DAT devices in Japan for several years, decided in 1990 to do as it had with the Betamax-proceed to market and let the chips fall where they may. The music publishers promptly filed a class action suit, ${ }^{240}$ Cahn थ. Sony. ${ }^{241}$ The pursuit of such litigation, in combination with the recording industry's refusal to license its works for the DAT medium, ultimately led to a settlement in the form of detailed legislation-the AHRA. ${ }^{242}$

One of the fascinating sidelights of this history is that Sony itself chose not to test the very safe harbor that it had fought so hard to establish just a few years previously. Notwithstanding the demonstrable noninfringing uses for DAT recorders-from recording public domain material to use in all manner of home and business recording applications, Sony declined to press to judgment in Cahn on the strength of its own Supreme Court Sony ruling. Part of the explanation for this change in strategy may lie in the fact that by the early 1990 s, Sony had diversified into the film and music industries. ${ }^{243}$ Its business divisions, and hence its shareholders, were on both sides of the case. In many respects, Sony has internalized the externality of enabling piracy though diversification of its business activities.

\section{Computers and Related Devices}

\section{Overview}

Although computers have emerged as a critical link in the unauthorized distribution of copyrighted works, they have avoided any direct assault by the content industries. The evolutionary path of this technology has played a central role in its judicial immunity. The microcomputer revolution was already well underway by the time that the Sony case was finally resolved. Time magazine proclaimed the personal computer as its "Person [Machine] of the Year" in 1982. ${ }^{244}$ Content industries had little appreciation of how this technology would ultimately disrupt and reshape their business models. ${ }^{245}$

239. Hans Fantel, Harmony Envelops the DAT, N.Y. TIMES, Aug. 6, 1989, at H26.

240. See John Burgess, Sony Sued Over Digital Recorders; Songuriter, Publishers Seek to Block Sales, WASH. POST, July 11, 1990, at B8.

241. No. 90 Civ. 4537 (S.D.N.Y. filed July 9, 1990).

242. See supra Part II.B.

243. See supra note 97.

244. See Otto Friedrich et al., The Computer Moves In, TIME, Jan. 3, 1983, at 14. For Time's 2006 "Person of the Year," see infra Part IV.C.7.

245. See Peter S. Menell, Envisioning Copyright Law's Digital Future, 46 N.Y.L. SCH. L. REV. $63,108-18(2002-2003)$. 
At the time, the recording industry was actively rolling out the $\mathrm{CD}$ format without any effort to encrypt its crown jewels-high quality digital recordings-because microcomputers were not capable of posing any real threat to the music or film industries in the 1980 s or early 1990s. They lacked the memory capacity or speed to copy the large amounts of information contained in film or music files. ${ }^{246}$

The economic threat posed by computers came into sharper focus in the mid-1990s with the increase in storage capacity, development of compression-decompression algorithms, and lowering of prices for entertainmentoriented computing machines for the consumer marketplace. ${ }^{247}$ With the inclusion of CD drives, software for ripping music files, and stereo speakers as standard equipment, the computer became a music storage and copying device like none before. ${ }^{248}$ But litigation against computer manufacturers was hardly an option, with or without the Sony safe harbor. By that point in time, personal computers had become a basic feature of economic and social life. The microcomputer industry was substantially larger than the music industries. Furthermore, there could be little question that microcomputers, as well as music accessories being sold with them, had predominantly noninfringing uses. Accordingly, copyright owners could not credibly assert secondary liability against the makers of computers, hard drives, or CD burners if personal use of lawfully obtained copyrighted music was fair use.

As computer companies increasingly configured and marketed computers for use by a younger generation, some of their advertising campaigns drew criticism from content owners. In 2001, Apple Computer's "Rip, Mix, Burn" advertising campaign struck many in the entertainment

246. In the sole case litigated under the AHRA, the Ninth Circuit commented:

Until recently, the Internet was of little use for the distribution of music because the average music computer file was simply too big: the digital information on a single compact disc of music required hundreds of computer floppy discs to store, and downloading even a single song from the Internet took hours. However, various compression algorithms (which make an audio file "smaller" by limiting the audio bandwidth) now allow digital audio files to be transferred more quickly and stored more efficiently.

RIAA v. Diamond Multimedia Sys. Inc., 180 F.3d 1072, 1073-74 (9th Cir. 1999).

247. See Menell, supra note 245, at 108-18.

248. Yet, less than a decade earlier, the music industries declined to bring computers into the legislative negotiations over the AHRA. As a key legislator at the time noted, the AHRA excludes from coverage material objects in which computer programs are fixed, "except for certain specialized statements or instructions that may be contained in CD's, digital audio tapes, and similar objects covered by the legislation." 138 CONG. REC. S8422 (daily ed. Jun. 17, 1992) (statement of Sen. DeConcini). 
industries as bordering on inducement of illegal activity. ${ }^{249}$ But Steve Jobs, Apple's president, was quick to defend the slogan as inviting consumers to rip (or copy) musical recordings of albums that they had purchased, prepare a custom mix of such files, and burn (or record) them. ${ }^{250}$ Whether or not that is how the consumer marketplace interpreted the campaign, content companies chose not to file any legal action. ${ }^{251}$ A year later, the music industries worked out a licensing arrangement that authorized Apple Computer to develop the iTunes online music store, which quickly emerged as the leading outlet for legal digital downloads of sound recordings. ${ }^{252}$

\section{Portable Digital Music Devices}

In 1998, Diamond Multimedia introduced the Rio, a portable hard drive capable of storing approximately one hour of music compressed using the MP3 file format. This product dramatically increased consumer interest in downloading MP3 files over the Internet and ripping sound recording files from CDs to computer hard drives and compressing them. Prior to the introduction of this product, the principal benefit that consumers could derive from downloading or ripping sound recordings was to listen to these files through headphones or speakers at their computers. The Rio rendered these files portable. In comparison to portable cassette players, the Rio 300 was more compact, easier to use, and less vulnerable to distortion when in motion.

The recording industry sued Diamond Multimedia ${ }^{253}$ under the AHRA, alleging that distributors of MP3 players were required to employ a Serial Copyright Management System and to pay royalties on sales of digital audio recording devices. Recognizing that the legislative bargain effectuated by the AHRA applied narrowly to digital audio recording devices (and not general computer technology), the Ninth Circuit held that the Rio device did not

249. See Amy Harmon, Piracy, or Innovation? It's Hollywood vs. High Tech, N.Y. TIMES, Mar. 14, 2002, at C1; cf. Jon Healey, Gateway Touts Online Music, L.A. TIMES, Mar. 27, 2003, at C6 (announcing Gateway's "RipBurnRespect" slogan, which promotes a more conciliatory message).

250. See Harmon, supra note 249.

251. At a time of prickly relations between Disney's Michael Eisner and Pixar's Steve Jobs, the former had threatened to retaliate against Apple Computer Corporation-also helmed by Jobs_over its "Rip, Mix, Burn" campaign. See Richard Verrier \& Claudia Eller, A Clash of CEO Egos Gets Blame in Disney-Pixar Split; Eisner and Jobs Had Personal Differences That Affected Their Business Relationship, Sources Say, L.A. TIMES, Feb. 2, 2004, at A1. But the contretemps blew over, and Disney ultimately acquired Pixar. See Laura M. Holson, Disney Agrees to Acquire Pixar in a $\$ 7.4$ Billion Deal, N.Y. TIMES, Jan. 25, 2006, at C1.

252. See Jon Healey, Labels Think Apple Has Perfect Pitch, L.A. TimES, Mar. 4, 2003, at C1.

253. See RIAA v. Diamond Multimedia Sys., Inc., 29 F. Supp. 2 d 624 (C.D. Cal. 1998), aff d on other grounds, 180 F.3d 1072 (9th Cir. 1999). 
implicate the AHRA and dismissed the action. Echoing the Supreme Court's decision in Sony that "time-shifting" fell within the fair use doctrine, the Ninth Circuit added its own dictum that "space-shifting" was "paradigmatic noncommercial personal use." 254 The court's ruling-that the AHRA's computer exemption "is not limited to the copying of programs, and instead extends to any copying from a computer hard drive ${ }^{, 255}$ - slammed the courthouse door on the RIAA's effort to use the AHRA to squelch digital portable music devices.

Of greater interest for the purposes of this Article, the RIAA chose not to allege that the MP3 device contributed to copyright infringement. This strategy no doubt reflected its considered judgment that the Sony staple article of commerce doctrine barred such an allegation. It should be noted, however, that such a claim would also have failed under the Sony dissent's "primary use" standard for secondary liability. When this case arose (before the advent of the peer-to-peer revolution), portable digital music devices were used predominantly to space shift a user's own sound recordings, which the Ninth Circuit believed to fall within the bounds of fair use. It would have also failed under application of the RAD tort framework. Therefore, MP3 device manufacturers could not be held liable for infringing uses absent evidence of inducement or control.

\section{Digital Encoding Technology}

Many other digital technologies can be used for copyright infringement. Camcorders, for example, can be used to videotape movies. Yet, Hollywood recognized that camcorders have predominantly noninfringing uses-such as for making home movies. Therefore, it has never pursued indirect liability lawsuits against the manufacturers of such devices. Instead, the studios have persuaded Congress to ban their use in theaters and impose strong penalties for their use in pirating motion pictures. ${ }^{256}$

\section{Digital Video Recorders}

Notwithstanding the focus of the Sony Betamax decision, the development of DVRs at the turn of the millennium reignited many of the controversies previously thought to have been laid to rest. The digital version of such technology brought several new capabilities (such as automated commercial

254. Diamond Multimedia, 180 F.3d at 1079.

255. Id. at 1078.

256. See Family Entertainment and Copyright Act of 2005, Pub. L. 109-9, 119 Stat. 218. For an analysis, see 4 NIMMER \& NIMMER, supra note 76, § 15.06[A]. 
skipping and the ability to share television shows with friends over the Internet), greater speed and convenience, as well as vast storage capacity unimaginable in 1984. With the release of the first DVRs by TiVo and ReplayTV in the spring of $1999,{ }^{257}$ Hollywood reevaluated the reach of the Somy decision. Although the staple article of commerce doctrine would seem to provide a strong defense to the basic time-shifting functionality, TiVo's and ReplayTV's viability would be determined less by Sony's design immunity principle than by these companies' willingness to work with content owners and broadcasters.

TiVo took the more conciliatory path, raising investment capital from key content industry players early in its development. This allowed content industry players some input into TiVo's product features and services as well as a basis for developing collaborative advertising initiatives. ${ }^{258}$ Content owners have thus far tolerated TiVo's business model. ${ }^{259}$

By contrast, ReplayTV took a far more aggressive approach to the design and marketing of its product line. ${ }^{260}$ It touted features enabling consumers to skip commercials and to transmit digital copies of television programming over the Internet to other ReplayTV owners. In November 2001, television networks and production studios brought suit against ReplayTV for contributory infringement. $^{261}$ The company invoked Sony's fair use reasoning and staple

257. See Lawrence J. Magid, Rewind, Replay and Unwind With These New High-Tech TV Devices, L.A. TIMES, May 10, 1999 , at C6.

258. See Ashley Dunn, TiVo Woos TV's Big Players With Its Set-Top Box; Technology: Investments Come Despite the Threat to Conventional Advertising Posed by Its Digital Recording Device, L.A. TIMES, July 28, 1999, at C1; Michael A. Hiltzik, NBC Allies With Firm That Challenges TV Traditions, L.A. TMMES, Jun. 9, 1999, at A1. TiVo is seeking to implement digital rights management technology to limit the duration that programming can be stored so as to prevent accumulation of large digital libraries by users. See Dan Tynan, Winners and Losers 2005, PC WORLD, Dec. 27, 2005, available at http://www.pcworld.com/news/article/0,aid,123923,00.asp.

259. But consider content owners' vigorous response when TiVo began developing technology to enable sharing over the Internet similar to ReplayTV. See CTR. FOR DEMOCRACY \& TECH., ALL EYES ON TIVO: THE BROADCAST FLAG AND THE INTERNET (2004), http://www.cdt.org/ copyright/20040928tivo-reply.pdf. The Federal Communications Commission ultimately approved the TiVoGuard Digital Output Protection Technology system. See Press Release, FCC, FCC Approves Digital Output Protection Technologies and Recording Method Certifications (Aug. 4, 2004), available at http://fjallfoss.fcc.gov/edocs_public/attachmatch/DOC-250532A1.doc.

260. Fred von Lohmann, ReplayTV Zaps Ads and Permits Show Swapping; Get Ready for the Next Big Copyright Battle, CAL. LAW., June 2002, at 30. The website for ReplayTV 5000 stated: "You can now choose to playback your recorded shows without the commercials using Commercial Advance .... Under controlled test conditions with major network daytime and prime time broadcasts, approximately 96\% [of] intraprogram commercials are eliminated." Matthew Scherb, Comment, Free Content's Future: Advertising, Technology, and Copyright, 98 Nw. U. L. REV. 1787, 1814 n.193, 1815 (2004) (quoting ReplayTV 5000 Features and Benefits, http://www.digitalnetworksna.com/video/ Replaytv5000/Replaytv_5000_features.asp (last visited Apr. 7, 2004)).

261. See Doug Isenberg, ReplayTV Lausuit: Napster Redux?, CNET NEWS.COM, Nov. 12, 2001, http://news.com.com/2010-1079-281601.html. 
article of commerce safe harbor in defending its products. Before the case could be resolved, however, financial pressures on the company, exacerbated by the costs of defending the litigation, drove it into bankruptcy. ${ }^{262}$ Its new owners agreed to drop the automatic commercial-skipping feature in exchange for dismissal of the lawsuit. ${ }^{263}$ Industry lawyers and scholars have speculated about whether the Sony decision would have shielded ReplayTV from liability even on its core time-shifting functionality if the litigation had proceeded to judicial resolution. ${ }^{264}$

Given the advances in commercial-skipping technology, ${ }^{265}$ content owners and broadcasters were poised to argue that the impact on the market for advertising was palpable. ${ }^{266}$ Yet, the counter to that argument is not hard to formulate: Although the preservation of commercials in Betamax playbacks may have played an important background role in the Justices' minds, the Sony majority placed little express weight on it. ${ }^{267}$ Instead, it reached a ruling that

262. See Jon Healey, Sonicblue Files for Chapter 11; The ReplayTV Maker, Which Has Been Sued by Copyright Holders, Says Debt Hurt the Company, L.A. TIMES, Mar. 22, 2003, at Cl.

263. Eric A. Taub, ReplayTV's New Owners Drop Features That Riled Hollywood, N.Y. TIMES, July 21, 2003, at C3. A suit brought by ReplayTV users was dismissed a year later on the grounds that ReplayTV had dropped the feature that was being tested in the lawsuit. See Paramount Pictures Corp. v. ReplayTV, 298 F. Supp. 2 d 921 (C.D. Cal. 2004); ReplayTV Users' Lawsuit Is Dismissed, L.A. TIMES, Jan. 13, 2004, at C2.

264. See, e.g., Aaron A. Hurowitz, Copyright in the New Millennium: Is the Case Against ReplayTV a New Betamax for the Digital Age?, 1 COMMLAW CONSPECTUS 145 (2003); Ethan O. Notkin, Television Remixed: The Controversy Over Commercial-Skipping, 16 FORDHAM INTELL. PROP. MEDIA \& ENT. L.J. 899 (2006); Randal C. Picker, The Digital Video Recorder: Unbundling Advertising and Content, 71 U. CHI. L. REV. 205 (2004).

265. See supra note 260 ("[A]pproximately 96\% [of] intraprogram commercials are eliminated.").

266. Surveys indicate that most DVR users skip a high percentage of commercials. See Benny Evangelista, Fast Forward to VCR's Future: Digital Recording Devices Threaten Its Reign, S.F. CHRON., Apr. 22, 2002, at El, available at http://sfgate.com/cgi-bin/article.cgi?ff/c/a/2002/04/22/BU15029.DTL (reporting a survey of DVRs users finding that 35 percent never watch commercials and that 60 percent watch them only occasionally). And unlike commercial skipping with older analog devices-which required some attention to what was being broadcast-DVRs can accomplish skipping without a glance.

267. The opinion recounts the status of technology as reflected in the record:

The pause button, when depressed, deactivates the recorder until it is released, thus enabling a viewer to omit a commercial advertisement from the recording, provided, of course, that the viewer is present when the program is recorded. The fast-forward control enables the viewer of a previously recorded program to run the tape rapidly when a segment he or she does not desire to see is being played back on the television screen.

Sony Corp. of Am. v. Universal City Studios, Inc., 464 U.S. 417, 423 (1984). The opinion likewise quotes the district court's ruling:

"It must be remembered, however, that to omit commercials, Betamax owners must view the program, including the commercials, while recording. To avoid commercials during playback, the viewer must fast-forward and, for the most part, guess as to when the commercial has passed. For most recordings, either practice may be too tedious. As defendants' survey showed, $92 \%$ of the programs were recorded with commercials and only $25 \%$ of the owners fast-forward through them. Advertisers will have to make the same kinds of judgments they do now about whether persons viewing televised programs actually watch the advertisements which interrupt them."

Id. at 452 n.36 (quoting Universal City Studios, Inc. v. Sony Corp. of Am., 480 F. Supp. 429, 468 (1979)). 
wholesale copying via Betamax of copyrighted broadcasts made over the air is noninfringing-without limiting that pronouncement in a way to avoid future technological advancement as to commercial squelching. Thus, a viewer who uses ReplayTV to copy the entirety of 24 as broadcast has not infringed on Twentieth Century Fox's copyright. The further question arises: How could a viewer possibly infringe by copying all of 24 but choosing not to copy the spot ads that occurred amidst its broadcast? Fox would need to craft an argument to the effect: "We have no problem with viewers copying $100 \%$ of our own works-but how dare they do so without simultaneously copying the works separately copyrighted by our advertisers?!?" Beyond the fact that Fox would appear to lack standing to complain about how advertisers' works have been treated, the latter would appear without any right to complain that viewers have failed to copy their own copyrighted advertisements. ${ }^{268}$ As technology progresses, thus does Sony's staple article of commerce legacy become curiouser and curiouser. ${ }^{269}$

\section{Anticircumvention Technology}

As noted above, ${ }^{270}$ the DMCA specifically overrides aspects of the Sony safe harbor that might otherwise apply to devices that circumvent technological protection measures. The content industries have shown little tolerance for devices or software that approach this line. Lawsuits have targeted all manner of distributors and publishers of decryption code. ${ }^{271}$

268. After Jonathan Tasini prevailed in the Supreme Court, establishing that the New York Times infringed his copyright when it copied his works and those of his fellow freelancers, he subsequently filed suit against the New York Times for failing to copy such articles! The Court had little difficulty dismissing such an outré claim. See N.Y. Times Co. v. Tasini, 533 U.S. 483 (2001); see also Tasini v. N.Y. Times Co., 184 F. Supp. 2d 350, 353 (S.D.N.Y. 2002).

269. By contrast, a tort framework avoids this conundrum. We have previously confronted the possibility of copying program broadcasts only without their attendant commercials, concluding that Sony could not be liable as of 1984 for its failure to disable commercial squelching. See Menell \& Nimmer, supra note 10, at 1019. Yet, to the extent that ReplayTV affirmatively decided in the 2000 s to enable commercial skipping, tort law would have to confront afresh, based on technology then extant, whether it should be held liable. See id.

270. See supra Part II.C.1.

271. See, e.g., 321 Studios v. Metro Goldwyn Mayer Studios, Inc., 307 F. Supp. 2d 1085 (N.D. Cal. 2004) (software for decrypting DVDs ); United States v. Elcom Ltd., 203 F. Supp. 2d 1111 (N.D. Cal. 2002) (software decrypting eBook reader); Universal City Studios, Inc. v. Reimerdes, 111 F. Supp. 2d 294, 310 (S.D.N.Y. 2000), aff d sub nom. Universal City Studios, Inc. v. Corley, 273 F.3d 429 (2d Cir. 2001) (software for decrypting DVDs); RealNetworks, Inc. v. Streambox, Inc., No. 2:99CV02070, 2000 WL 127311 (W.D. Wash. Jan. 18, 2000) (product decrypting streaming technology). 


\section{Peer-to-Peer Technology}

As discussed previously, copyright owners have taken an aggressive stance against general purpose peer-to-peer enterprises, notwithstanding the Sony staple article of commerce defense. ${ }^{272}$ Although neither the plaintiffs in these cases nor their content industry-backed amici directly attacked the underlying basis of the Sony staple article of commerce safe harbor, they asserted that it either did not apply in their cases or that the peer-to-peer technology at issue did not have substantial noninfringing use.

\section{Video Distribution}

A fifteen-year old set up a webcam in her bedroom to confess the nottoo-eventful history of her home-schooled life in a strict, religious household. In mid-2006, millions of people worldwide got sucked into the saga of Bree, otherwise known as "lonelygirl15."273 As it turned out, she was really nineteen, a New Zealander, and an actress at that-and her real name was Jessica Rose, not Bree. But by this time, lonelygirl 15 had become a sensation, much to the delight of the Marin County screenwriter and filmmaker who had dreamt her up, now represented by Hollywood powerhouse Creative Artists Agency. ${ }^{274}$

How did it happen? Thanks to YouTube, a do-it-yourself website where anyone can post home videos. ${ }^{275}$ A search on that site at present reveals 5821 postings related to the scheme, including home movies that rant at lonelygirl 15 for being a fake, offer homage at the delicious deception, praise the McLuhanesque reversal, ${ }^{276}$ or fantasize about a thousand things

272. See supra Part III.B.

273. See lonelygirl15, http://en.wikipedia.org/wiki/Lonelygirl15 (last visited Aug. 5, 2007).

274. Virginia Heffernan \& Tom Zeller, Jr., Well, It Tums Out That Lonelygirl Really Wasn't, N.Y. TIMES, Sept. 13, 2006, at C1.

275. The implications reach vastly greater than copyright; perhaps they go right to the core of political accountability. As noted by the Libyan-born former minister of trade for Venezuela:

A VIDEO SHOWS a line of people trudging up a snow-covered footpath. A shot is heard; the first person in line falls. A voice-over says, "They are killing them like dogs." Another shot, and another body drops to the ground. A Chinese soldier fires his rifle again. Then a group of soldiers examines the bodies.

These images were captured in the Himalayas by a member of a mountaineering expedition who claims to have stumbled on the killing. The video first aired on Romanian television, but it only gained worldwide attention when it was posted on YouTube, the video-sharing website.

Moisés Naím, The YouTube Effect, L.A. TIMES, Dec. 20, 2006, at A31.

276. For a fabulous account of the new technologies and their antecedents in Andy Warhol and Marshall McLuhan, see RICHARD A. LANHAM, THE ECONOMiCS OF ATTENTION (2006). 
with her (most, of course, sexual). ${ }^{277}$ But those offerings are simply the tip of YouTube's iceberg: "To tens of millions of people, YouTube is the go-to source for whatever is hot in pop culture at the moment." ${ }^{278}$ Indeed, the You of YouTube was instrumental in Time magazine's selection of You as "Person of the Year" in 2006. ${ }^{279}$

What are the copyright implications? Given that all concerned consented to the initial production, the uploading of the original lonelygirl15 does not trigger infringement liability. Theoretically, some of the fan tributes could constitute unauthorized derivative works of lonelygirl15, but the producers seem to be more grateful for the attention than concerned about exercising maximal control of their adaptation right. ${ }^{280}$ So the direct implications of this particular work are small.

But the larger picture is rife with copyright implications. For the same technology that allows Bill and Jane to post their trek up El Capitan allows Boris to upload the bootleg recording he made at the

277. See http://www.youtube.com/results?search_query=lonelygirl15\&search=Search (last visited Dec. 29, 2006).

278. Phil Kloer, You Beaut, YouTube, AGE (Australia), Dec. 26, 2006, available at http:/www.theage.com/au/news/biztech/you-beaut-YouTube/2006/12/22/1166895269590.html. The variety is seemingly infinite:

In recent days I've seen Ella Fitzgerald in 1957, at her peak, singing Angel Eyes in Amsterdam; the Penguin Cafe Orchestra on Britain's South Bank Show; Bob Dylan sound-checking for his 1984 Letterman appearance backed by members of the Plugz; Fela Kuti jamming with Ian Anderson and Jack Bruce on German TV in 1983; the Stooges in 1970; Funkadelic in 1979; Conway Twitty and Loretta Lynn singing Easy Loving; the prelapsarian Mothers of Invention performing King Kong; pre-paralyzed Robert Wyatt in the Soft Machine; the KLF on Top of the Pops with Tammy Wynette; Liberace playing Flight of the Bumblebee....

Robert Lloyd, YouTube Is Trip Doun the Rabbit Hole, RECORD (Ontario), Dec. 27, 2006, at D6.

279. Lev Grossman, Time Person of the Year: You, TiME, Dec. 25, 2006, at 38. The article stated:

Who actually sits down after a long day at work and says, I'm not going to watch

'Lost' tonight. I'm going to turn on my computer and make a movie starring my pet iguana? I'm going to mash up 50 Cent's vocals with Queen's instrumentals? I'm going to blog about my state of mind or the state of the union or the steak-frites at the new bistro down the street? Who has that time and that energy and that passion?

The answer is, you do. And for seizing the reins of the global media, for founding and framing the new digital democracy, for working for nothing and beating the pros at their own game, Time's Person of the Year for 2006 is you.

Id.; see George F. Will, Full Esteem Ahead, WASH. POST, Dec. 21, 2006, at A29 ("Narcissism is news? Evidently.").

280. See 17 U.S.C. $\$ 106(2)$ (2000 \& Supp. IV 2004). 
recent Bow Wow concert. ${ }^{281}$ Thus can some acts of copyright infringement coexist on the site with countless noninfringing works.

One reaction to this scenario is for the owners of YouTube to simply rely on the Sony safe harbor. After all, unlike Napster and Aimster, which were merely capable in theory of substantial noninfringing use, ${ }^{282}$ YouTube in actuality hosts massive amounts of noninfringing content, perhaps even the vast preponderance of its offerings being beyond legal reproach. But after Google purchased YouTube for $\$ 1.65$ billion, it took a very different approach ${ }^{283}$ :

The site late last week began purging copyrighted material from Comedy Central, including clips from YouTube stalwarts like "The Daily Show With Jon Stewart," "The Colbert Report" and "South Park."

The action was "a result of third-party notification by Comedy Central," according to one such e-mail message sent to a YouTube user, Jeff Reifman, who broke the news on the Web site NewsCloud.

A week earlier, nearly 30,000 clips of TV shows, movies and music videos were taken down after the Japanese Society for Rights of Authors, Composers and Publishers cited copyright infringement. ${ }^{284}$

That strategy reflects accommodation. Google has reportedly reached deals with "leading copyright holders" allowing it to "post copyrighted music videos and other content in exchange for sharing advertising revenue." ${ }^{285}$ Indeed, Google itself held back over $\$ 200$ million of the purchase price in order "to cover losses or possible legal bills for the frequent copyright violations on YouTube's video-sharing site."286

Notwithstanding those efforts to root out unauthorized content from the service, contrary movement also exists. There are indications that postings on YouTube drive traffic back to the excerpted shows from which

281. That bootleg violates 17 U.S.C. $\$ 1101(2000)$. To the extent that the artist was singing a previously recorded (or transcribed) song, it likewise violates 17 U.S.C. $\$ 501$ (2000 \& Supp. II 2002).

282. See supra Parts III.B.1-III.B.2.

283. See Noam Cohen, YouTube Is Purging Copyrighted Clips, N.Y. TIMES, Oct. 30, 2006, at $\mathrm{C} 8$.

284. Id.

285. YouTube 'Should Check Copyright,' BBC NEWS, Dec. 5, 2006, http://news.bbc.co.uk/ 1/hi/technology/6209414.stm.

286. AP Wire, Google Retains Part of YouTube Payout, L.A. TIMES, Nov. 15, 2006, at C2; see id. ("The reserve could signal that Google is trying to insulate itself from a possible onslaught of lawsuits aimed at the large number of pirated videos posted on YouTube ...."). 
the videos emanate-witness the 5 percent spike in viewings of David Letterman's Late Show after clips from it became one of the most popular offerings on YouTube. ${ }^{287}$

At the same time that Google was dealing, others were holding back. The world's largest music company responded by filing an infringement action against News Corp. and its subsidiary MySpace, "the popular social networking Web site, for allowing users to upload and download songs and music videos." ${ }^{288}$ It decided to sue "despite an announcement last month by MySpace that it had adopted technology to identify copyrighted material in order to enable compensation for the owners." ${ }^{289}$ Moreover, after suit was filed, MySpace announced "that it planned to deploy a new tool that would let copyright owners flag videos posted by users without permission; it said it would remove any videos that received such a marking." ${ }^{290}$

In March 2007, Google found itself in a similar predicament. ${ }^{291}$ Viacom, the parent company of MTV, Nickelodeon, and Comedy Central, sued Google over user-posted clips of its copyrighted programs on YouTube. ${ }^{292}$ Like News Corp., Google has focused its energies on employing and developing technologies that can efficiently and effectively

287. See Steve Johnson, You May Have Shone in '06, but Your Net Worth Didn't Rise, CHI. TRIB., Dec. 29, 2006, at 2. New media pose new possibilities:

NBC used YouTube, nimbly, to dance around censors. Its year-end "Saturday Night Live" video, a song about an explicit Christmas present, aired on the network with the song's key word, a vulgarism for a male anatomical feature, bleeped out. But the network posted it, uncensored, on NBC.com and YouTube right away, and that version (search "special Christmas box") became among the most discussed and rapidly circulated viral videos since last year's "SNL" classic, the rap parody "Lazy Sunday."

It was the buzz over "Lazy Sunday," not coincidentally, that took YouTube from fringe to mainstream, Internet audience measurement executives have said. Then, NBC quickly asked YouTube to take the video down, restricting its availability to the network's own site, the one it draws ad revenue from. Now NBC works with YouTube Id. as a virtual bulletin board. This change took less than a year.

288. Jeff Leeds, Universal Music Sues MySpace for Copyright Infringement, N.Y. TIMES, Nov. 18,2006 , at $\mathrm{C} 3$. That suit follows on the heels of Universal's copyright infringement suits against Grouper Networks and against Bolt. Id. (Disclosure: Counsel for Universal Music Group is Irell \& Manella LLP, to which one of the current authors is of counsel.)

289. Id.

290. Id.

291. In addition, Robert Tur, who made copyright doctrine in the past pursuing networks for rebroadcasting his video footage of the beating of Reginald Denny in the 1992 Los Angeles riots, see L.A. News Serv. v. Tullo, 973 F.2d 791 (9th Cir. 1992), more recently has filed suit against YouTube, alleging 5500 unauthorized accesses to the footage of that same beating, see Complaint para. 12, Robert Tur v. YouTube, Inc., No. CV06-4436 (C.D. Cal. July 14, 2006), available at http://pub.bna.com/eclr/064436.pdf.

292. See Miguel Helft \& Geraldine Fabrikant, Viacom Sues Google Over Video Clips on Its Sharing Web Site, N.Y. TIMES, Mar. 14, 2007, at C1. 
filter out unauthorized copyrighted works. ${ }^{293}$ Although Google's public response emphasizes Sony's staple article of commerce defense and the OCILLA provisions, its internal activities reinforce the observation that the market does not put a lot of faith in Sony's staple article of commerce safe harbor.

\section{Sony's Vector: The Subsequent Marketplace Experience}

Based on the foregoing, how has the Sony staple article of commerce doctrine fared in the marketplace? On the one hand, it would be absurd to maintain that the opinion has had no effect on corporate actors in designing which products to offer. But, on the other, it is almost as erroneous to maintain that it has insulated technology companies from secondary liability to the extent that its broad language suggests.

Copyright owners have exerted substantial pressure upon technology companies to exercise restraint in the design of their products and services, as reflected in DAT, DVR, and anticircumvention markets. The filing of the ReplayTV lawsuit and its resolution largely favorable to the content owners suggest that the Sony staple article of commerce safe harbor is hardly an invulnerable shield, either in the eyes of the content industries or the marketplace. ${ }^{294}$ That lawsuit, as well as the DAT and peer-to-peer experience, resulted in the implementation of significant design changes in the marketplace, suggesting that the shadow of the Sony decision may more closely approximate the RAD framework than the broad safe harbor ascribed to the Sony rule. ${ }^{295}$

The ferment over YouTube is revealing. Napster and Aimster were minimally capable of substantial noninfringing use, even though they in fact were used overwhelmingly to infringe..$^{296}$ By contrast, YouTube is not only capable of hosting noninfringing content (of which lonelygirl15 may be the most celebrated), but, in addition, actually hosts countless thousands of such products from home users only too eager to share their personal cinéma vérité. If the language of the Sony case is to be taken literally,

293. See Kevin J. Delaney et al., Policing Web Video With 'Fingerprints'-Sharing Sites Say Technology Could Help Them Identify, Remove Unauthorized Clips, WALL ST. J., Apr. 22, 2007, at B1.

294. Cf. Litman, supra note 5, at 956-57 (suggesting that the Sony third-party liability safe harbor has proven to be far from clear in practice).

295. See supra Part I.B.

296. See supra Parts III.B.1-III.B.2. 
then the company should be deemed paradigmatically on the safe side..$^{297}$ Further, by simply taking down objectionable content in response to content owners' duly filed notices of infringement, YouTube falls into the additional safe harbor that Congress created for its benefit in OCILLA as part of the Digital Millennium Copyright Act. ${ }^{298}$ For both those reasons, Google could adopt a what-me-worry attitude towards future copyright liability ${ }^{299}$

Yet, as we have seen, it has done no such thing. Instead, it has created a $\$ 200$ million reserve against future infringement liability. ${ }^{300}$ It has additionally gone further than the DMCA envisions, agreeing to take down not only particularly noticed sites but also thousands of additional videos. ${ }^{301}$ MySpace has agreed to do likewise. ${ }^{302}$ These actions reveal that Sony is scarcely the chief determinant of how decisions get made in the boardroom. To be sure, Google and MySpace will undoubtedly direct their counsel to highlight the staple article of commerce doctrine as a defense to any copyright infringement suit. ${ }^{303}$ But when it comes time to honestly evaluate the litigation risks, the company will considerably discount the odds that any product "capable of substantial noninfringing uses" will, in fact, escape liability on that basis.

That experience shows the resilience of tort law's principles in adapting copyright's liability regime, even after its nominal discard by the Supreme Court in Sony. ${ }^{304}$ Not content to rely on escaping liability because its services are capable of substantial noninfringing uses, Google

297. As will be explored more fully in the final installment in this series, an additional possibility is liability on a theory of inducing copyright infringement. See Menell \& Nimmer, supra note 221.

298. See supra Part IV.C.2.

299. For copyright owners, that posture is less than satisfactory, as the takedown notices mandated by OCILLA lead to a "whack-a-mole situation," such that when the proprietor "demands that the site's administrators remove a video, users can simply upload the file again." Andy Greenberg, YouTube's Doppelganger, ForBES, Nov. 29, 2006, available at http://www.forbes.com/ technology/2006/11/28/piracy-networks-copyright-tech_cx_ag_1129video.html.

300. See supra Part IV.C.7.

301. See id.

302. See id.

303. In addition, the companies, of course, will vigorously assert the safe harbor that the DMCA added to the Copyright Act in OCILLA. See 17 U.S.C. $\$ 512$ (2000); Natali T. Del Conte, Will Google Pay for YouTube Infringements?, PC MAG., Oct. 10, 2006, available at http://www.pcmag.com/article2/0,1895,2027482,00.asp. At play here, however, is a double-edged sword:

"The problem is that the more they go into editorial control, the less they can rely on the DMCA to protect them," said Randy Broberg, head of the intellectual property practice group at Allen Matkins LLP. "If you exercise editorial censorship, it becomes YouTube's content, which would make them more liable."

Del Conte, supra.

304. See supra Part I.C. 
has decided to ameliorate harm because the foreseeable risks of harm posed by YouTube can be reduced or avoided by the adoption of a reasonable alternative, namely, taking down infringing videos and acting to forestall their future posting. In these particulars, Google's actions show the triumph, in the real world, of tort law's reasonable alternative design standard over patent law's staple article of commerce doctrine. ${ }^{305}$

\section{FACING THE FUTURE}

Although Sony nominally crowned patent law's staple article of commerce doctrine as the decisor for copyright cases, as a practical matter, the ancien régime reigns sovereign. The inherent logic of the tort framework still dominates actual analysis, as opposed to the nominal fealty to Sony that courts outwardly profess. As shown above, various jurists have gravitated away from the Sony test and toward a tort-based analysis over the years since the case was decided. Moreover, Congress itself has pushed the copyright system in this direction through its forays into digital technology policy-requiring, inter alia, that DAT players incorporate electronics to prevent second-generation copies and prohibiting circumvention of technological protection measures.

Sony's aftermath has highlighted the flaws in the Court's unwarranted turn to patent law as a guide for indirect liability. Since the Sony case, Congress has approached digital technology with considerable cautionbanning record and software rental, regulating DAT technology, and restricting circumvention of technological protection measures. Each of these activities was capable of substantial noninfringing use, yet Congress chose the path of balance and design responsibility. Congress has shown no such proclivity in the patent arena. The courts have also found the Sony framework far less compelling in application. The Sony safe harbor has proven unavailing to a variety of peer-to-peer enterprises. The marketplace also seems to reflect a great concern for balancing enhanced functionality with content protection, as reflected in the evolution of DVR technology.

A pronouncement that has been on the books for over twenty years without ever having been directly followed is prima facie suspect on that basis alone. In the recent series of cases involving peer-to-peer technology, courts have struggled with the application of the Sony safe harbor to

305. See supra Part I.B. 
highly parasitic business models that pose serious threats to the content industries. In none of these cases have courts immunized the defendants from liability; yet, they have adhered to the fig leaf of a flawed, analog-age decision. Paradoxically, the legacy of Sony's turn towards patent law has been to force courts to find a way around the Supreme Court's decision rather than unjustly applying patent law. Thus, although courts and commentators continue to pay lip service to the Sony staple article of commerce doctrine, the practical reality lies closer to the reasonable alternative design standard that the Supreme Court should have followed. 